This is the peer reviewed version of the following article:

Blereau, E. and Clark, C. and Taylor, R. and Johnson, T. and Fitzsimons, I. and Santosh, M. 2016. Constraints on the timing and conditions of high-grade metamorphism, charnockite formation and fluid-rock interaction in the Trivandrum Block, southern India. Journal of Metamorphic Geology. 34 (6): pp. 527-549.,

which has been published in final form at http://doi.org/10.1111/img.12192

This article may be used for non-commercial purposes in accordance with Wiley Terms and Conditions for Self-Archiving at http://olabout.wiley.com/WileyCDA/Section/id-

820227.html\#terms 


\title{
Constraints on the timing and conditions of high-grade metamorphism, charnockite formation, and fluid-rock interaction in the Trivandrum Block, southern India
}

\author{
E. BLEREAU ${ }^{*}$, C. CLARK ${ }^{1}$, R. J. M. TAYLOR ${ }^{1}$, T. E. JOHNSON¹, I. C. W. FITZSIMONS ${ }^{1}$, M. \\ SANTOSH ${ }^{2,3}$
}

1Department of Applied Geology, The Institute of Geoscience Research (TIGeR), Curtin University, GPO Box U1987, Perth WA 6845, Australia.

${ }^{2}$ School of the Earth Sciences and Resources, China University of Geosciences (Beijing), 29 Xueyuan Road, Beijing 100083, China.

${ }^{3}$ Centre for Tectonics, Resources and Exploration, Department of Earth Sciences, University of Adelaide SA 5005, Australia

*Corresponding author E-mail: eleanore.blereau@postgrad.curtin.edu.au

\section{Short Title: Metamorphism and charnockites in Trivandrum}

Article type : Original Article

\begin{abstract}
Incipient charnockites have been widely used as evidence for the infiltration of $\mathrm{CO}_{2}$-rich fluids driving dehydration of the lower crust. Rocks exposed at Kakkod quarry in the Trivandrum Block of southern India allow for a thorough investigation of the metamorphic evolution by preserving not only orthopyroxene-bearing charnockite patches in a host garnet-biotite felsic gneiss, but also layers of garnet-sillimanite metapelite gneiss. Thermodynamic phase equilibria modelling of all three bulk compositions indicates consistent peak metamorphic conditions of $830-925^{\circ} \mathrm{C}$ and $6-9$ kbar with retrograde evolution involving suprasolidus decompression at hightemperature. These models suggest that orthopyroxene was most likely stabilised close to the metamorphic peak as a result of small compositional heterogeneities in the host garnet-biotite gneiss. There is insufficient evidence to determine whether the heterogeneities were inherited from the protolith or introduced during synmetamorphic fluid flow. U-Pb geochronology of monazite and zircon from all three rock types constrains the peak of metamorphism and orthopyroxene growth to have occurred between the onset of high-grade metamorphism at c. $590 \mathrm{Ma}$ and the onset of melt crystallization at c. $540 \mathrm{Ma}$. The majority of metamorphic zircon growth occurred during protracted melt crystallization between c. 540-510 Ma. Melt crystallization was followed by the influx of aqueous, alkali-rich fluids likely derived from melts crystallizing at depth. This late fluid flow led to retrogression of orthopyroxene, the observed outcrop pattern and to the textural and isotopic modification of monazite grains at c. 525-490 Ma.
\end{abstract}

Key words: Charnockite, granulite, geochronology, phase equilibria modelling, fluid.

This article has been accepted for publication and undergone full peer review but has not been through the copyediting, typesetting, pagination and proofreading process, which may lead to differences between this version and the Version of Record. Please cite this article as doi: $10.1111 /$ jmg. 12192

This article is protected by copyright. All rights reserved. 


\section{INTRODUCTION}

The occurrence of orthopyroxene-bearing patches within otherwise orthopyroxene-free biotite- or hornblende-bearing host rocks, referred to as incipient or arrested charnockite, has been used as a key piece of evidence to support the notion that the infiltration of a low- $\mathrm{H}_{2} \mathrm{O}$ activity, $\mathrm{CO}_{2}$-rich fluid drives dehydration of the lower crust and the transition from amphibolite to granulite facies rocks (Newton, 1992; Santosh \& Omori, 2008; Touret \& Huizenga, 2012; Newton \& Tsunogae, 2014). Whether dehydration of the lower crust to form granulite facies rocks was driven dominantly by interaction with $\mathrm{CO}_{2}$-rich fluids (Newton et al., 1980; Newton, 1989) or by the removal of hydrous partial melt (Fyfe, 1973; White \& Powell, 2002) is still the subject of debate.

Incipient charnockites have been described at many localities within the Trivandrum Block of southern India (Hansen et al., 1987; Stähle et al., 1987; Raith \& Srikantappa, 1993; Perchuk et al., 2000; Ravindra Kumar, 2004; Rajesh \& Santosh, 2012; Endo et al., 2013; Taylor et al., 2014). Exposures are generally confined to quarries, most of which contain either garnet-biotite gneiss (referred to locally as leptynite) and associated charnockite or more aluminous metapelitic gneiss (khondalite). However, a previously unstudied quarry at Kakkod (Fig. 1) preserves all three main rock types (incipient charnockite, host garnet-biotite gneiss and metapelitic gneiss), potentially enabling a study of charnockite formation within the context of the broader metamorphic history of the Trivandrum Block. We combine petrography, phase equilibria modelling, $\mathrm{U}-\mathrm{Pb}$ geochronology and REE analyses of key minerals from the three main lithotypes to better understand the conditions and timing of their formation. In addition, we use textural information from monazite and zircon to infer an episode of fluid flux in these rocks, and, coupled with $\mathrm{U}-\mathrm{Pb}$ age data and the rare earth element compositions of garnet, zircon and monazite, investigate the relationship between the timing of peak metamorphism, charnockite formation and fluid influx.

\section{GEOLOGICAL SETTING}

The Southern Granulite terrane (SGT) of southern India, located to the south of the Dharwar Craton, has been subdivided into a series of crustal tectonic domains (Fig. 1). These are the Coorg (Santosh et al., 2015, 2016), Salem (Clark et al., 2009b), Nilgiri (Raith et al., 1990; Harris et al., 1994) and Madras Blocks (Harris et al., 1994; Santosh et al., 2003b) in the north, which are separated from more southerly domains by the Palghat-Cauvery shear zone system (Collins et al., 2007a; Clark et al., 2009a). To the south of the Palghat-Cauvery shear zone system are the northern and southern Madurai Blocks that are distinguished on the basis of different protolith ages (Plavsa et al., 2012; Plavsa et al., 2014; Clark et al., 2015). The Trivandrum Block is located to the south of the southern Madurai Block, from which it is separated by the Achankovil Zone (Drury et al., 1984; Sacks et al., 1997; Cenki et al., 2004; Chetty et al., 2006; Taylor et al., 2014). The southernmost domain, the Nagercoil Block, lies at the southern tip of peninsular India (Johnson et al., 2015; Kröner et al., 2015) (Fig. 1).

Cambrian deformation and granulite facies metamorphism in the Trivandrum Block has generally been attributed to the Malagasy Orogeny (550-510 Ma) and linked to the assembly of Gondwana (Collins \& Pisarevsky, 2005; Santosh et al., 2009; Collins et al., 2014). The rocks in the Trivandrum Block are dominated by garnet-and biotitebearing felsic gneiss (leptynite) and garnet-sillimanite-biotite or garnet-biotite- 
sillimanite-cordierite gneiss (khondalite), with minor calc-silicate, quartzite and mafic granulite (Ravindra Kumar et al., 1985; Chacko et al., 1987; Yoshida et al., 1991; Chacko et al., 1992; Jackson \& Santosh, 1992; Raith \& Srikantappa, 1993; Harley \& Santosh, 1995; Braun et al., 1998; Fonarev et al., 2000; Nandakumar \& Harley, 2000; Nair \& Chacko, 2002; Morimoto et al., 2004; Shabeer et al., 2005; Braun, 2006; Tadokoro et al., 2008; Endo et al., 2013; Collins et al., 2014; Harley \& Nandakumar, 2014). The Trivandrum Block also contains particularly good examples of orthopyroxene-bearing felsic granulites (hereafter termed charnockites) that are commonly developed within garnet-biotite gneiss (Ravindra Kumar et al., 1985; Hansen et al., 1987; Raith \& Srikantappa, 1993; Endo et al., 2013; Taylor et al., 2014). Charnockites within the Trivandrum Block have two main modes of occurrence: (1) decimetre-scale incipient charnockites with diffuse contacts that generally occur within the garnet-biotite gneisses and are interpreted to have a metamorphic origin; and (2) massive charnockite that forms discrete outcrops that have no reported contact relationships with garnetbiotite or metapelitic gneisses, and which are often ascribed an igneous origin or interpreted as an end-product of the incipient charnockitisation process (Ravindra Kumar et al., 1985; Srikantappa et al., 1985; Harley \& Santosh, 1995; Rajesh \& Santosh, 2004; Rajesh \& Santosh, 2012; Touret \& Huizenga, 2012). This study focuses on incipient charnockites.

The pressure-temperature-time $(P-T-t)$ evolution recorded by rocks of the Trivandrum Block is the subject of on-going debate. Some authors have suggested peak temperatures in excess of $950^{\circ} \mathrm{C}$ and pressures up to $\sim 12$ kbar (Morimoto et al., 2004; Tadokoro et al., 2008). By contrast, other studies have documented lower pressures and a decrease in metamorphic grade towards the southwest from $900-1050{ }^{\circ} \mathrm{C}$ at $\sim 8.5-9.5$ kbar at the southern margin of the Achankovil Zone to $800-900{ }^{\circ} \mathrm{C}$ and $4.5-6.0 \mathrm{kbar}$ further south (Chacko et al., 1996; Nandakumar \& Harley, 2000; Pattison et al., 2003; Shabeer et al., 2005; Collins et al., 2014). However, there is general consensus that the rocks followed a clockwise $P-T$ evolution (Cenki et al., 2004; Shabeer et al., 2005; Tadokoro et al., 2008; Collins et al., 2014).

A large proportion of $\mathrm{U}-\mathrm{Pb}$ zircon data from rocks across the Trivandrum Block suggest zircon grew at c. $515 \mathrm{Ma}$ (Collins et al., 2007b), which was originally interpreted to constrain the age of peak metamorphism and later interpreted as the age of melt crystallization (Taylor et al., 2014). Taylor et al. (2014) constrained the age of peak metamorphism in the Trivandrum Block to $c$. 580-560 Ma based on U-Pb dating of monazite. Harley \& Nandakumar (2014) suggested high temperature conditions prevailed until 545-535 Ma. Following peak metamorphism, Taylor et al. (2014) suggested that an episode of alkali-bearing fluid ingress occurred at c. 500 Ma resulting in the modification of the accessory phases and the development of the distinctive patchiness observed in the outcrop.

\section{FIELD RELATIONSHIPS AT KAKKOD QUARRY}

The dominant rock type within the quarry at Kakkod is a pale-grey garnet-biotite gneiss (Fig. 2a). The gneiss has a centimetre-scale gneissic foliation defined by biotite with numerous pink garnet porphyroblasts. Garnet occurs mainly within 5-10 mm wide leucosome veins (Fig. 2b) that are parallel to the regional foliation, as well as within larger leucogranite sheets that vary from $5 \mathrm{~cm}$ to $3 \mathrm{~m}$ in thickness. The leucogranite is

This article is protected by copyright. All rights reserved. 
coarser grained than the garnet-biotite gneiss and lacks biotite. The garnet in the leucogranite sheets typically occurs as grain aggregates 1-2 cm across and, less commonly, as large euhedral to subhedral grains $1.0-1.5 \mathrm{~cm}$ across. At the western end of the quarry (Fig. 2a) a layer of migmatitic garnet-sillimanite-cordierite gneiss (hereafter metapelitic gneiss) is exposed (Fig. 2c,d). No direct contact between the garnet-biotite gneiss and the metapelitic gneiss is exposed. The two rock types are always separated by a thin $(5-10 \mathrm{~cm})$ garnet-bearing leucogranite sheet that is similar in mineralogy to the leucogranite described above (Fig. 2d). A number of small dykes ( $10-12 \mathrm{~cm}$ wide) of undeformed coarse-grained monazite- and biotite-bearing but garnet-absent pegmatite cross cut the foliation within the garnet-biotite gneiss (Fig. 2e).

Incipient charnockites at Kakkod are characterized by the occurrence of diffuse, irregular dark patches that occur exclusively within the garnet-biotite gneiss (Fig. 2a,f). These patches comprise orthopyroxene-bearing quartzofeldspathic granofels ranging from $50 \mathrm{~cm}$ to $2 \mathrm{~m}$ across and have no clear preferred orientation. A 2-5 cm transition zone between the garnet-biotite gneiss and the charnockite is characterised by a decrease in the abundance of biotite and a gradual change in colour into the darker green charnockite (Fig. 2f). Incipient charnockites rarely cross cut the leucogranite, although charnockite patches occur commonly at the margins of some of the larger leucogranite bodies. In this paper we present and discuss data collected from five samples that are representative of these various rock types.

\section{PETROGRAPHY \\ Garnet-biotite gneiss}

The garnet-biotite gneiss (I11-004K) is migmatitic and dominated by quartz (30-35\%) and feldspar (35-40\%). Garnet (10-14\%) occurs as two distinct populations. Type-1 garnet forms isolated rounded porphyroblasts $(\sim 3-6 \mathrm{~mm})$ containing inclusions of biotite (Fig. 3a) and are located within the melanosome. Type- 2 garnet occurs as subhedral to anhedral clusters of grains $2 \mathrm{~mm}$ or less in size containing inclusions of both quartz and biotite and are located within the leucosome (Fig. 3b). Biotite ( $10 \%$, 1-2 $\mathrm{mm}$ ) is interpreted to record two generations of growth. The first, which occurs as inclusions within garnet (Fig. 3a,b - Bt 1) and as laths defining the gneissic foliation, is interpreted to have been stable during the prograde evolution and at the metamorphic peak. The second generation, which occurs as randomly orientated grains and replacing garnet at its margins (Fig. 3a,b-Bt 2), is interpreted as retrograde. The sample also contains minor ilmenite $(\sim 1 \%, \sim 1 \mathrm{~mm})$. Most of the (partially sericitized) feldspar is perthite (30-35\%, 2-4 $\mathrm{mm}$ ) with minor plagioclase $(2-5 \%, 1-2 \mathrm{~mm})$; myrmekite is also present. The peak assemblage of the garnet-biotite gneiss sample I11-004K is interpreted as garnet, K-feldspar, quartz, biotite, ilmenite, plagioclase and melt. Along with some biotite, minor chlorite is interpreted to be retrograde.

Large grains of monazite $(\sim 240 \mu \mathrm{m})$ occur within K-feldspar and quartz, with some grains occurring near or directly adjacent to biotite. Back-scattered electron imaging (BSE) of monazite reveals low BSE response cores with complex irregular recrystallized zones displaying a high BSE response (Fig. 4a). Zircon ( 100 $\mu \mathrm{m})$ displays oscillatory-zoned cores under cathodoluminescence (CL) imaging with uniform CL response rims that sometimes truncate the zoning within the cores (Fig. 4b).

This article is protected by copyright. All rights reserved. 


\section{Transitional zone between garnet-biotite gneiss and charnockite}

Sample I11-004C was collected from a gradational transition zone between garnetbiotite gneiss and charnockite (i.e. similar to Fig. 2f). Biotite (5-10\%, 0.5-1.0 mm) and garnet $(5-10 \%, 1-1.5 \mathrm{~mm})$ are present but less abundant than in the garnet-biotite gneiss. The remainder of the sample is dominated by quartz (35-40\%, 1-4 mm), perthite (35-40\%, 1-3 mm) and plagioclase (5-10\%, 1-3 mm). Garnet has irregular grain boundaries with quartz and biotite inclusions, similar to type- 2 garnet from the garnet-biotite gneiss. Garnet is commonly surrounded by an intergrowth of biotite and quartz, consistent with a reaction with melt (Fig. 3c). Some myrmekite is present. Orthopyroxene $(0.5-2.0 \mathrm{~mm})$ is completely retrogressed to chlorite and other finegrained hydrous phases (Fig. 3c). Monazite is similar to that within the garnet-biotite gneiss, with low BSE response cores and high BSE response recrystallized zones (Fig. $4 \mathrm{e}$ ). Likewise, the zircon grains have a similar appearance to those in the garnet-biotite gneiss, with oscillatory-zoned cores and homogeneous rims.

\section{Garnet-bearing charnockite}

Sample I11-008C, a charnockite patch from within the garnet-biotite gneiss, is coarse grained and darker in colour than the host gneiss. The sample is dominated by irregular grains of feldspar (40-45\% perthite $1-3 \mathrm{~mm}$; $5-10 \%$ plagioclase, $1-3 \mathrm{~mm}$ ) and quartz (35-40\%, 1-4 mm) with some myrmekite. Orthopyroxene (2-3\%, 0.5-2 mm) occurs as discrete subhedral grains in contact with quartzofeldspathic minerals (Fig. 3d, e, f) and does not appear to replace any ferromagnesian minerals, suggesting that it grew in equilibrium with other matrix minerals in the charnockite. All orthopyroxene grains are retrogressed at their margins and along cleavage plains (Fig. 3d,e) to a fine-grained aggregate of hydrous minerals including chlorite, with many grains completely pseudomorphed (Fig. 3f). Minor biotite (2-5\%, 1-2 $\mathrm{mm}$ ) generally occurs adjacent to or replacing orthopyroxene (Fig. 3d,f). Garnet (2-5\%) forms irregular porphyroblasts 1-4 $\mathrm{mm}$ in diameter containing quartz inclusions, similar to the type-2 garnet of the garnetbiotite gneiss (Fig. 3f). Ilmenite $(\sim 1 \%, \sim 1 \mathrm{~mm})$ and chlorite occur as minor phases. The main equilibrium assemblage of this sample is interpreted to be orthopyroxene, garnet, K-feldspar, quartz, plagioclase, ilmenite and melt. Given suggestions that incipient charnockite forms by fluid-driven recrystallization, we acknowledge that this might not be the peak assemblage (an issue we address below using phase equilibria modelling). Biotite and chlorite are considered to be retrograde.

Monazite $(\sim 240 \mu \mathrm{m})$ shows uniform BSE response with no obvious zoning (Fig $4 \mathrm{e})$. On the basis of CL imaging, zircon within the charnockite occurs in two forms: (i) grains with oscillatory-zoned cores with either uniform or sector-zoned rims $(\sim 160$ $\mu \mathrm{m})$ and, (ii) equant 'soccer-ball' grains $(\sim 130 \mu \mathrm{m})$ (Vavra et al., 1996; Schaltegger et al., 1999; Kelly \& Harley, 2005) (Fig. 4f).

\section{Metapelitic gneiss}

The metapelitic gneiss (TB-14-025) is meso- to melanocratic and migmatitic, comprising layers of melanosome and leucosome. Garnet $(20-22 \%, 0.5-4.5 \mathrm{~mm})$ is present in both melanosome and leucosome as two different types. Type- 1 garnet, which is more abundant in melanosome, is anhedral, inclusion-rich (including sillimanite, plagioclase and biotite), elongate, and aligned parallel to the foliation (Fig. 3h). Type-2 garnet is inclusion-poor, anhedral (Fig. 3g) and occurs within the 
leucosome. Sillimanite (20-25\%) is abundant within the melanosome and defines the foliation, occurring as euhedral grains ranging from 0.5 to $2.0 \mathrm{~mm}$ in length (Fig. 3c). Sillimanite also occurs as inclusions in type-1 garnet that define a foliation subparallel to the matrix foliation. Perthite $(15-18 \%, 0.5-4.0 \mathrm{~mm})$ is present both in the melanosome and leucosome, whereas quartz (8-10\%, 1-2 $\mathrm{mm}$ ) is present only in the leucosome. Spinel (2-3\%, 0.2-1.0 mm) occurs as anhedral grains in the matrix of the quartz-free melanosome. The rock also contains minor plagioclase $(2 \%, 0.1-0.5 \mathrm{~mm})$, ilmenite $(1 \%, 0.1-1.0 \mathrm{~mm})$ and pyrite $(<1 \%, 0.1-1.0 \mathrm{~mm})$. Twinned and variably pinitised cordierite $(\sim 20 \%, 1-4 \mathrm{~mm})$ surrounds garnet, sillimanite, ilmenite, spinel and biotite. Matrix biotite (7-10\%, 0.1-2.0 mm) occurs as two generations. The first is present as inclusions within garnet and anhedral grains enclosed by cordierite (Fig. 3i Bt 1). The second generation occurs as randomly orientated grains within the matrix and replacing garnet in both the melanosome and leucosome (Fig. $3 g-B t 2$ ). The peak assemblage of this sample is interpreted to be garnet, ilmenite, plagioclase, K-feldspar, biotite and melt with sillimanite and spinel only present in the melanosome and quartz only present in the leucosome. Cordierite and some of the biotite is interpreted to be retrograde.

Zircon $(\sim 200 \mu \mathrm{m})$ occurs within quartz, feldspar and near ilmenite, biotite and sillimanite. Monazite $(\sim 60-100 \mu \mathrm{m})$ is present as inclusions within garnet, cordierite, $\mathrm{K}$-feldspar, quartz and adjacent to sillimanite, ilmenite and spinel. Monazite generally shows low BSE response cores with lobate high BSE response recrystallized zones (Fig. $4 \mathrm{~g}$ ) although some grains are uniform (Fig. 4g). Zircon is recrystallized with most primary oscillatory-zoned cores replaced by uniform low-CL response domains (Fig. 4h). Some grains also have rims with uniform CL response (Fig. 4h).

\section{Pegmatite}

Sample I11-006V is dominated by quartz (20-25\%), feldspar ( 60\%) and biotite (15$20 \%$ ), all of which are 2 to $4 \mathrm{~mm}$ across. The majority of feldspar is perthite comprising an approximate 1:1 ratio of sodic to potassic feldspar lamellae, along with minor plagioclase $(\sim 10 \%)$. Yellow monazite $(\sim 1 \mathrm{~mm})$ is found both as clusters and isolated grains. It occurs as inclusions within biotite, within and in close association with ilmenite ( 1\%, 1-2 mm), and rarely within feldspar (both perthite and minor plagioclase). BSE imaging of monazite reveals little or no zoning in the majority of grains. Unzoned monazite shows high to low BSE response with a few grain showing low BSE response recrystallized zones (Fig. 4d).

\section{ANALYTICAL METHODS \\ Phase equilibria modelling}

Metamorphic $P-T$ conditions were constrained using isochemical $P-T$ pseudosections in the model pelite system $\mathrm{Na}_{2} \mathrm{O}-\mathrm{CaO}-\mathrm{K}_{2} \mathrm{O}-\mathrm{FeO}-\mathrm{MgO}_{-} \mathrm{Al}_{2} \mathrm{O}_{3}-\mathrm{SiO}_{2}-\mathrm{H}_{2} \mathrm{O}-\mathrm{TiO}_{2}-\mathrm{O}$

(NCKFMASHTO). Pseudosections were calculated using THERMOCALC 3.40i and the internally consistent thermodynamic dataset of Holland \& Powell (2011)(specifically the tc-ds62 dataset generated on 06/02/14). The phases considered were: garnet (Grt), silicate melt (Liq), ternary feldspar (Kfs, Pl), muscovite (Ms), biotite (Bt), orthopyroxene (Opx), cordierite (Crd), ilmenite (Ilm) and magnetite-spinel (Mt, Spl). Activitycomposition models are from White et al. (2014a). Mineral abbreviations follow Kretz (1983) and Whitney \& Evans (2010).

This article is protected by copyright. All rights reserved. 
Bulk rock compositions for I11-004K, I11-008C and TB-14-025 (garnet-biotite gneiss, charnockite and metapelitic gneiss) were determined by X-ray fluorescence analysis using a Panalytical 2404 instrument at Franklin and Marshall College, Pennsylvania; ferric and ferrous iron contents were determined by titration at the same institution. The bulk compositions (as mol.\%) used in pseudosections are provided in Table 1. Although Mn-bearing solution models have recently been calibrated (White et al., 2014b), Mn has a negligible effect on phase stability at high-T and was excluded from the model system (Johnson et al., 2015). Modelled $\mathrm{H}_{2} \mathrm{O}$ contents are taken from the total loss-on-ignition amounts in XRF data, except for the charnockitic composition in which a lower value of $1 \mathrm{~mol}$ \% was used to account for the significant hydrous retrogression of orthopyroxene in this sample.

Based on petrographic observations, none of the samples contained magnetite as a peak phase, an interpretation supported by energy dispersive spectral analysis using the TM3030 Tabletop Microscope (using Swift ED3000 at 15kv), in which all analysed opaque phases were ilmenite. Preliminary phase equilibria calculations using the measured amount of ferric iron oxide $\left(\mathrm{Fe}_{2} \mathrm{O}_{3}\right.$, modelled in THERMOCALC as $\mathrm{O}$ in the bulk composition, Diener \& Powell (2010); Table 1) contained no fields in which the interpreted peak assemblage did not coexist with magnetite, implying some oxidation of the rock after the metamorphic peak (either during exhumation and/or weathering of the rock or during sample preparation). To better constrain $\mathrm{Fe}_{2} \mathrm{O}_{3}$ contents at the metamorphic peak, $T / P-M_{F e 203}$ pseudosections were calculated for all modelled rocks, where $M_{\mathrm{Fe} 203}$ is a binary compositional range expressing variable ferric iron contents (molecular proportion of $\mathrm{Fe}_{2} \mathrm{O}_{3}$ in the rock) from the titrated values (at $\mathrm{X}=0$ ) to a minimal $\mathrm{Fe}_{2} \mathrm{O}_{3}$ content in the rock of 0.01 mol.\% (at X=1; see Figs $\mathrm{S} 1-3$ ). These diagrams show that magnetite is removed from the interpreted peak assemblage at appropriate $P-T$ conditions ( $>5 \mathrm{kbar}, \sim 900^{\circ} \mathrm{C}$, see below) if $\mathrm{X}$ is increased to $\sim 0.7$, equivalent to decreasing the molecular proportion of $\mathrm{Fe}_{2} \mathrm{O}_{3}$ in the rock to $30 \%$ of the measured value. Thus, for the charnockite and garnet-biotite gneiss, which have very similar measured $\mathrm{Fe}_{2} \mathrm{O}_{3}$ concentrations of 0.39 and 0.36 mol.\% respectively, we have used a single $\mathrm{Fe}_{2} \mathrm{O}_{3}$ concentration of $0.11 \mathrm{~mol} \%$ for pseudosection modelling, while a corresponding value of $0.40 \mathrm{~mol}$. \% was used for the metapelitic gneiss (also equal to $\sim 30 \%$ of the measured value).

\section{SHRIMP U-Pb geochronology}

Grains of monazite from all samples (and zircon from metapelitic gneiss) were extracted from polished thin sections (in situ) along with immediately adjacent minerals as 2-mm diameter pucks using a coring piece on a Dremel drill. Nineteen pucks were mounted and cast in a 25-mm diameter epoxy disk. Samples were cleaned and coated with a $30 \mu \mathrm{m}$ gold coat to ensure conductivity during SIMS analysis. In addition to thin section mounts, grain separates of monazite and zircon were prepared via traditional methods of disaggregation, magnetic and heavy liquid separation. These grains were mounted in 25-mm diameter epoxy discs, polished then cleaned before applying a 30 $\mu \mathrm{m}$ gold coat. Mounts were characterised using BSE imaging for monazite with a Zeiss EVO 40XVP SEM and Tescan Mira3 FESEM, and CL imaging for zircon with a Philips XL 30 and a Tescan Mira3 FESEM (both at the John de Laeter Centre of Mass Spectrometry housed at Curtin University).

This article is protected by copyright. All rights reserved. 
$\mathrm{U}-\mathrm{Pb}$ isotopic data of zircon and monazite were collected using the Sensitive High Resolution Ion Microprobe (SHRIMP II) based in the John de Laeter Centre, Curtin University. The mass filtered $\mathrm{O}_{2}^{-}$primary beam strength was $0.3 \mathrm{nA}$ with a $10 \mu \mathrm{m}$ spot size for monazite, and $1.9 \mathrm{nA}$ with a $20 \mu \mathrm{m}$ spot size for zircon. A 6-scan duty cycle and a mass resolution of $\approx 5000$ were used during analysis (Kennedy \& de Laeter, 1994; de Laeter \& Kennedy, 1998). Data was processed using SQUID II and Isoplot 3.75 (Ludwig, 2009) with the correction of measured isotopic ratios for common Pb based on Stacey \& Kramers (1975). Standards were located in a separate mount for the analysis of monazite and zircon in thin section and this mount was Au-coated at the same time as their respective samples. For monazite, INDIA (Curtin internal laboratory standard, 509 Ma) was used as a primary standard (Korhonen et al., 2011) and GM-3 as a secondary standard (Curtin internal laboratory standard, $488 \mathrm{Ma}$ ). The same standards were used in the monazite grain mount. NBS glass $(610,612)$ was used for all zircon and monazite analyses to calibrate the position of the ${ }^{204} \mathrm{~Pb}$ peak. For zircon analyses, BR266 (Stern \& Amelin, 2003) was used as a primary standard and Temora 2 (Black et al., 2003) as a secondary standard in both grain and in situ mounts. Secondary standards (Temora 2 (417 Ma) and GM-3 (488 Ma)) for all sessions were within error (Temora 2: $414 \pm 4 \mathrm{Ma}$, $413 \pm 5 \mathrm{Ma}$; GM-3: $488 \pm 5 \mathrm{Ma}, 488 \pm 3 \mathrm{Ma}$ ) of reported ages. The ${ }^{207} \mathrm{~Pb} /{ }^{235} \mathrm{U}$ monazite ages were used for reported ages and ranges over ${ }^{206} \mathrm{~Pb} /{ }^{238} \mathrm{U}$ ages because of reduced effects of fractionation via incorporation of intermediate daughter products from ${ }^{230} \mathrm{Th}$ decay (Kirkland et al., 2009). Based on our data ${ }^{207} \mathrm{~Pb} /{ }^{235} \mathrm{U}$ and ${ }^{206} \mathrm{~Pb} /{ }^{238} \mathrm{U}$ monazite ages are within $\sim 5 \%$ discordance and are near equivalent to each other, allowing for use of Terra-Wasserburg concordia plots. A high degree of discordance and smearing along concordia is typical of $\mathrm{U}-\mathrm{Pb}$ zircon and monazite data from southern India.

Recrystallized, inherited zircon show a large variation in discordance (up to 48\%) due to partial $\mathrm{U}-\mathrm{Pb}$ resetting. In comparison the majority of metamorphic zircon is less than $10 \%$ discordant. For the purpose of calculating metamorphic ages concordance is defined by the $2 \sigma$ error ellipse overlapping with concordia (Spencer et al., 2015). Metamorphic zircon age ranges are defined using ${ }^{206} \mathrm{~Pb} /{ }^{238} \mathrm{U}$ as these grains are younger than c. $1500 \mathrm{Ma}$ (Spencer et al., 2015). Pooled age data from multiple grains is reported either as a weighted mean age (if MSWD <2.5) or a range of ages (if MSWD > $2.5)$. Error ellipses on concordia diagrams are at the $2 \sigma$ level. Weighted means were calculated at 95\% confidence. Errors cited for individual spot analysis in the text and data tables include errors from counting statistics, errors from the common $\mathrm{Pb}$ correction and $\mathrm{U}-\mathrm{Pb}$ calibration errors based on reproducibility of $\mathrm{U}-\mathrm{Pb}$ measurements of the standard, and are at the $1 \sigma$ level. A minimum error of $1 \%$ was assigned to the external spot-to-spot error to reflect the long-term performance of the SHRIMP. Zircon was not analysed from the transition zone due to its similar morphology to that within the garnet-biotite gneiss. Complete data tables for all monazite and zircon geochronology can be found in Tables S1 and S2.

\section{LA-ICP-MS REE analysis of monazite, zircon and garnet}

Rare earth element (REE) data were collected using Laser Ablation Inductively Coupled Plasma Mass Spectrometry (LA-ICP-MS) on an ASI Resolution M-50 with a 193-nm wavelength Ar-F excimer laser with an Agilent 7700 mass spectrometer at the GeoHistory Facility, John de Laeter Centre, Curtin University. Analyses were made directly on top of all SHRIMP spots in monazite and zircon in both in situ and grain mounts. Garnet (core and rims) within the garnet-biotite gneiss (I11-004K), charnockite (I11-008C) and metapelitic gneiss (TB-14-025) were also analysed in thin

This article is protected by copyright. All rights reserved. 
sections. Garnet was analysed using a $50-\mu \mathrm{m}$ spot size, zircon with a $23-\mu \mathrm{m}$ spot size and monazite with a $33-\mu \mathrm{m}$ spot size. NIST glasses were used as reference material, specifically the 610 and 612 glasses with 610 used as the primary standard.

Stoichiometric major elements were used for calibration of trace elements in each phase. Stoichiometric Si was used as the internal standardisation element for both zircon (14.76 wt\%) and garnet (18 wt\%). Ce (230526 ppm) was used as the internal standardisation element for monazite (Buick et al., 2010). All REE ppm values were normalized to CI chondrite values from Anders \& Grevesse (1989), given as $\mathrm{X}_{\mathrm{N}}$ values (X = relevant element). Europium anomalies were evaluated using $\mathrm{Eu} / \mathrm{Eu}^{*}$ values $\left(\mathrm{Eu} / \mathrm{Eu}^{*}\right.$ $\left.=\mathrm{Eu}_{\mathrm{N}} / 0.5^{*}\left(\mathrm{Sm}_{\mathrm{N}}+\mathrm{Gd}_{\mathrm{N}}\right)\right)$. Time-resolved data for all data points were reviewed following each session using the Iolite software package (Paton et al., 2010, 2011) and any monazite analyses that sampled inclusions (e.g. thorite) were removed. LREE data from zircon and garnet are not reported because relatively high values indicate that the LAICP-MS technique has sampled LREE-rich inclusions as well as the host mineral (e.g. LREE in zircon and garnet indicate monazite inclusions). Complete REE data tables can be found in Tables S3-S5.

\section{RESULTS}

\section{Phase equilibria modelling}

In the $P-T$ pseudosection for sample I11-004K (garnet-biotite gneiss; Fig. 5a) the calculated solidus is located at $\sim 700-725{ }^{\circ} \mathrm{C}$. The stability field for the inferred peak assemblage of garnet, ilmenite, K-feldspar, plagioclase, quartz and melt, both with and without biotite is highlighted, as natural biotite contains fluorine that will expand its stability to temperatures higher than predicted in the model system. These fields encompass a $P-T$ range of 4.6 to $>10 \mathrm{kbar}$ and $790-940^{\circ} \mathrm{C}$. At lower pressures orthopyroxene and/or cordierite are predicted to be stable, neither of which occur in this sample.

In the $P-T$ pseudosection for sample I11-008C (charnockite; Fig. $5 \mathrm{~b}$ ) the calculated solidus is located at $\sim 735-750{ }^{\circ} \mathrm{C}$. The stability field for the interpreted peak assemblage of garnet, orthopyroxene, ilmenite, plagioclase, K-feldspar, quartz and melt occurs at $820-950^{\circ} \mathrm{C}$ at $4.9-9.0 \mathrm{kbar}$. At lower temperatures biotite is predicted. Magnetite is predicted to be stable at pressures of $<7 \mathrm{kbar}$ at $700{ }^{\circ} \mathrm{C}$ and $<5 \mathrm{kbar}$ at 950 ${ }^{\circ} \mathrm{C}$, and therefore defines the lower pressure limit of the peak field. However, given that the bulk $\mathrm{Fe}_{2} \mathrm{O}_{3}$ content is adjusted specifically to move the magnetite stability field to lower pressure, the $P-T$ position of this field does not provide independent constraints on the metamorphic conditions in our samples. Instead, we take the lack of cordierite, which is predicted to be stable at $<4.5 \mathrm{kbar}$, to provide a more robust lower pressure limit to peak conditions in this sample.

In the $P-T$ pseudosection for sample TB-14-025 (metapelitic gneiss; Fig. $5 \mathrm{c}$ ) the calculated solidus is located at $\sim 730-760{ }^{\circ} \mathrm{C}$. Magnetite is predicted only at low pressures (below $7 \mathrm{kbar}$ at $700{ }^{\circ} \mathrm{C}$ and below 4 kbar at $920^{\circ} \mathrm{C}$ ) for the chosen $\mathrm{Fe}_{2} \mathrm{O}_{3}$ content. The bulk composition of this sample contains both melanosome and leucosome and the pseudosection generated for this composition has quartz stable across the entire $P-T$ range. Due to spinel only being stable in the quartz-free melanosome we have chosen to ignore it from the peak assemblage for this whole rock pseudosection. The stability field of the interpreted peak assemblage of garnet, ilmenite, sillimanite, plagioclase, K-feldspar, quartz and melt (both with and without biotite to account for 
likely differences between the natural and modelled stabilities of biotite) occurs at conditions of $740-960^{\circ} \mathrm{C}$ and $>5.6 \mathrm{kbar}$. Cordierite, which is stable at $<6-6.5 \mathrm{kbar}$, provides the lower pressure limit to the peak assemblage.

\section{Monazite SHRIMP U-Pb dating}

Monazite was analysed in thin section from a variety of textural settings such as inclusions in K-feldspar, quartz, garnet, cordierite and adjacent to ilmenite, biotite, sillimanite and spinel. No relationship was found between the textural location of accessory phases and their respective ages. Complete data tables for monazite $\mathrm{U}-\mathrm{Pb}$ analyses can be found in Table S1.

\section{Garnet-biotite gneiss}

Fifteen analyses were performed on monazite grains from sample I11-004K. Core and recrystallized zone textures were targeted that had previously been identified through BSE imaging. Low BSE response monazite cores from the garnet-biotite gneiss yielded a range of ${ }^{207} \mathrm{~Pb} /{ }^{235} \mathrm{U}$ spot ages from $594 \pm 8$ to $529 \pm 10 \mathrm{Ma}(\mathrm{n}=6)$ and $\mathrm{Th} / \mathrm{U}$ ratios of 16.6-26.6. The recrystallized zones yield a range of ${ }^{207} \mathrm{~Pb} /{ }^{235} \mathrm{U}$ spot ages from $587 \pm 10$ to $507 \pm 17 \mathrm{Ma} \mathrm{(n=9)}$ and Th/U ratios of 30.6-87.1 (Fig. 6a).

\section{Transition zone}

Twenty-nine spots from ten grains were analysed from sample I11-004C. Ten analyses of low BSE response monazite cores yielded a weighted mean ${ }^{207} \mathrm{~Pb} /{ }^{235} \mathrm{U}$ age of $584 \pm 8$ Ma (MSWD=0.7, $\mathrm{n}=10$ ) and Th/U ratios of 17.1-23.5, with the high BSE response recrystallized zones giving a range of ${ }^{207} \mathrm{~Pb} /{ }^{235} \mathrm{U}$ spot ages from $593 \pm 13$ to $517 \pm 13 \mathrm{Ma}$ and Th/U ratios of 20.0-98.4 (Fig. 6b).

\section{Charnockite}

Only two monazite grains were found in sample I11-008C. Both appear uniform, with no zoning or high BSE response recrystallized zones, and yielded a weighted mean ${ }^{207} \mathrm{~Pb} /{ }^{235} \mathrm{U}$ age of $505 \pm 12 \mathrm{Ma}(\mathrm{MSWD}=1.8, \mathrm{n}=6)$ and Th/U ratios of 6.9-83.9 (Fig. 6c).

\section{Metapelitic gneiss}

Seventeen monazite grains were analysed from sample TB-14-025. The concordant monazite cores gave a range of ${ }^{207} \mathrm{~Pb} /{ }^{235} \mathrm{U}$ ages from $586 \pm 5$ to $512 \pm 6 \mathrm{Ma}(\mathrm{n}=12)$ and $\mathrm{Th} / \mathrm{U}$ ratios of 4.0-45.9. A few discordant cores define a discordia with an upper intercept of $1946 \pm 24 \mathrm{Ma}$ (MSWD=0.66, n=5) (Fig. 6d). The lower intercept of this discordant array is based on the onset of high-temperature conditions using the oldest metamorphic monazite spots and should not be interpreted as a true metamorphic age. The majority of ages are younger than c. $590 \mathrm{Ma}$ and plot close to the concordia line (Fig. 6d,e). The recrystallized zones yielded a range of ${ }^{207} \mathrm{~Pb} / 235 \mathrm{U}$ ages from $595 \pm 6$ to $513 \pm 7 \mathrm{Ma}(\mathrm{n}=15)$ and $\mathrm{Th} / \mathrm{U}$ ratios of $6.2-47.8$.

\section{Pegmatite}

A total of 17 analyses were conducted on monazite from sample I11-006V. The cores of nine grains gave a range of ${ }^{207} \mathrm{~Pb} /{ }^{235} \mathrm{U}$ spot ages from $586 \pm 12$ to $510 \pm 9 \mathrm{Ma}(\mathrm{n}=14)$ and Th/U ratios of 11.0-30.3. The low BSE response outer recrystallized zones yielded a younger concordant population with a weighted mean ${ }^{207} \mathrm{~Pb} /{ }^{235} \mathrm{U}$ age of $512 \pm 10 \mathrm{Ma}$ $(\mathrm{MSWD}=1.5, \mathrm{n}=3$ ) and Th/U ratios of 5.5-17.1 (Fig. 6f). 


\section{Zircon SHRIMP U-Pb dating}

Zircon was analysed within grain mounts except for the metapelitic gneiss sample, which was analysed in thin section. Complete data tables for zircon $\mathrm{U}-\mathrm{Pb}$ analyses can be found in Table S2.

\section{Garnet-biotite gneiss}

A total of 11 zircon $\mathrm{U}-\mathrm{Pb}$ analyses were performed on the garnet-biotite gneiss (I11$004 \mathrm{~K})$. Two oscillatory cores were analysed with ages falling along a discordia trend $(M S W D=2.0, n=11)$ that has a poorly constrained upper intercept at $2015 \pm 140 \mathrm{Ma}$ and a lower intercept of $513 \pm 20 \mathrm{Ma}$, a mean age of the range of rim analyses (Fig. $6 \mathrm{~g}$ ). The rims yielded a range of ${ }^{206} \mathrm{~Pb} /{ }^{238} \mathrm{U}$ spot ages from $538 \pm 11$ to $492 \pm 6 \mathrm{Ma}(\mathrm{n}=9)$.

\section{Charnockite}

Twenty-nine $\mathrm{U}-\mathrm{Pb}$ analyses were performed on zircon from the charnockite (I11-008C). The oscillatory zoned cores fall along a discordia with a poorly defined upper intercept of $2238 \pm 110 \mathrm{Ma}$ and a lower intercept $572 \pm 23 \mathrm{Ma}$ (MSWD=0.43, n=5; the lower intercept is based on the onset of high-temperature conditions using the oldest rims and should not be interpreted as a true metamorphic age) (Fig. 6h). The rims yielded a range of ${ }^{206} \mathrm{~Pb} /{ }^{238} \mathrm{U}$ spot ages from $589 \pm 23 \mathrm{Ma}$ to $496 \pm 6(\mathrm{n}=22)$. Zircon from this sample with a 'soccer-ball' morphology yielded a concordant population with a weighted mean ${ }^{206} \mathrm{~Pb} /{ }^{238} \mathrm{U}$ age of $563 \pm 14 \mathrm{Ma}$ (MSWD=1.7, n=5) (Fig. 6i).

\section{Metapelitic gneiss}

Five $\mathrm{U}-\mathrm{Pb}$ analyses were performed in thin section on zircon from the metapelitic gneiss (TB-14-025). This number was limited by the very low abundance of zircon and by cracks that left only a small portion of each grain available for analysis. Zircon grains were contained in quartz and K-feldspar and adjacent to ilmenite, biotite and sillimanite. No relationship was found between the textural location of accessory phases and their respective ages. The rim and recrystallized areas yielded a single concordant age population with a weighted mean ${ }^{206} \mathrm{~Pb} /{ }^{238} \mathrm{U}$ age of $552 \pm 17 \mathrm{Ma}(\mathrm{MSWD}=0.38, \mathrm{n}=5$ ) (Fig. 6j).

\section{Rare Earth Element mineral chemistry}

Key REE concentrations and ratios for monazite, zircon and garnet have been summarised in Table 2 . A complete table of analysed trace elements for these phases can be found in Tables S3, S4 and S5 respectively.

\section{Monazite}

Garnet-biotite gneiss (111-004K). The cores and recrystallized zones have similar negative M-HREE slopes $\left(\mathrm{Yb}_{\mathrm{N}} / \mathrm{Gd}_{\mathrm{N}}\right.$ of $0.001-0.008$ and $0.001-0.004$ respectively), but with a relative HREE enrichment of almost one order of magnitude more in the most of the cores $\left(\mathrm{Lu}_{\mathrm{N}}=75-146 \mathrm{ppm} /\right.$ chondrite, $\left.\mathrm{n}=8\right)$ compared to the recrystallized zones $\left(\mathrm{Lu}_{\mathrm{N}}=13-59 \mathrm{ppm} / \mathrm{chondrite}, \mathrm{n}=13\right)$ (Fig. 7a). A few cores have HREE concentrations similar to the recrystallized zones $\left(\mathrm{Lu}_{N}=16-30 \mathrm{ppm} /\right.$ chondrite, $\left.\mathrm{n}=4\right)$. Some of the cores have less pronounced Eu anomalies than the recrystallized zones with $\mathrm{Eu} / \mathrm{Eu}^{*}$ values of 0.002-0.006 and 0.002-0.004, respectively. 
Transition zone (111-004C). Monazite from the transition zone sample shows similar MHREE negative slopes for cores and recrystallized zones with $\mathrm{Yb}_{\mathrm{N}} / \mathrm{Gd}_{\mathrm{N}}$ values of 0.001 0.002 and $0.0004-0.002$ respectively. The recrystallized zones are relatively more depleted in the M-HREE $\left(\mathrm{Lu}_{\mathrm{N}}=8-57 \mathrm{ppm} /\right.$ chondrite, $\mathrm{n}=21$ ) compared to the cores ( $\mathrm{Lu}_{\mathrm{N}}$ $=62-82 \mathrm{ppm} /$ chondrite, $\mathrm{n}=9)$. One core had similar HREE concentration to recrystallized zones ( $21 \mathrm{ppm} /$ chondrite). The Eu anomaly is the same from core to recrystallized zones with $\mathrm{Eu} / \mathrm{Eu}^{*}$ values of 0.001-0.004 (Fig. 7b).

Charnockite (I11-008C). Monazite from the charnockite shows no internal variation and has a M-HREE negative slope with $\mathrm{Yb}_{\mathrm{N}} / \mathrm{Gd}_{\mathrm{N}}$ of 0.001 and $\mathrm{Eu} / \mathrm{Eu}^{*}$ of 0.002 (Fig. 7c).

Metapelitic gneiss (TB-14-025). Monazite cores from the metapelitic gneiss have a negative M-HREE slope $\left(\mathrm{Yb}_{\mathrm{N}} / \mathrm{Gd}_{\mathrm{N}}=0.0003-0.026\right)$. Those cores that preserved old discordant $\mathrm{U}-\mathrm{Pb}$ ages have relatively high HREE concentrations $\left(\mathrm{Lu}_{\mathrm{N}}=778-942\right.$ $\mathrm{ppm} / \mathrm{chondrite,} \mathrm{n}=2$ ) that are higher than those of recrystallized zones, while other cores have lower concentrations $\left(\mathrm{Lu}_{\mathrm{N}}=5-425 \mathrm{ppm} /\right.$ chondrite, $\left.\mathrm{n}=10\right)$ comparable to those in the recrystallized zones ( $\left.\mathrm{Lu}_{\mathrm{N}}=3-253 \mathrm{ppm} / \mathrm{chondrite}, \mathrm{n}=9\right)$ (Fig. $7 \mathrm{~d}$ ). The recrystallized zones also have a negative M-HREE slope $\left(\mathrm{Yb}_{\mathrm{N}} / \mathrm{Gd}_{\mathrm{N}}=0.0002-0.007\right)$ and a large spread of HREE concentrations, although the majority are lower than those of core analyses $\left(\mathrm{Lu}_{\mathrm{N}}=3-7 \mathrm{ppm} / \mathrm{chondrite}, \mathrm{n}=6\right)$. Some of the cores preserve less pronounced negative Eu anomalies than the recrystallized zones with $\mathrm{Eu} / \mathrm{Eu}^{*}$ values of $0.002-0.075$ and $0.002-0.034$ respectively.

Pegmatite (I11-006V). The cores and recrystallized zones both show a negative M-HREE slope with $\mathrm{Yb}_{\mathrm{N}} / \mathrm{Gd}_{\mathrm{N}}=0.004-0.006$ and 0.004-0.005 respectively (Fig. 7e). The cores are slightly more enriched in HREE than the recrystallized zones. The Eu anomaly is the same for the cores and recrystallized zones with $\mathrm{Eu} / \mathrm{Eu}^{*}$ values of $0.003-0.005$ and 0.004-0.005 respectively.

\section{Zircon}

Garnet-biotite gneiss (111-004K). Two distinct HREE patterns are present. Oscillatoryzoned cores show a steep positive M-HREE slope with $\mathrm{Yb}_{\mathrm{N}} / \mathrm{Gd}_{\mathrm{N}}=8-16$ (Fig. 7f). These cores have a less pronounced negative Eu anomaly (Eu/Eu* $0.70-0.97)$. Zircon rims show a flat HREE pattern $\left(\mathrm{Yb}_{\mathrm{N}} / \mathrm{Gd}_{\mathrm{N}}=0.7-1.3\right)$ on a chondrite-normalised plot. The rims exhibit a more pronounced negative Eu anomaly $\left(\mathrm{Eu} / \mathrm{Eu}^{*}=0.03-0.38\right)$.

Charnockite (I11-008C). Zircon in the charnockite displays two distinct HREE patterns. Oscillatory-zoned cores have a positive M-HREE slope $\left(\mathrm{Yb}_{\mathrm{N}} / \mathrm{Gd}_{\mathrm{N}}=11.7-14.26\right)$, and a small Eu anomaly (Eu/Eu*=0.13-0.28) (Fig. 7g). Zircon rims show a less positive MHREE slope $\left(\mathrm{Yb}_{\mathrm{N}} / \mathrm{Gd}_{\mathrm{N}}=1.4-9.69\right)$ and have similar to more pronounced Eu anomalies than the cores $\left(\mathrm{Eu} / \mathrm{Eu}^{*}=0.004-0.060\right)$. Soccer ball zircon displays a similar M-HREE slope $\left(\mathrm{Yb}_{\mathrm{N}} / \mathrm{Gd}_{\mathrm{N}}=2.09-2.63\right)$ and concentrations to the zircon rims (Fig. $7 \mathrm{~g}$ ) with all Eu values below detection limits.

Metapelitic gneiss (TB-14-025). Recrystallized zircon in the metapelite shows a near flat M-HREE slope, except for one analysis (PA1-1.1) having a negative M-HREE slope $\left(\mathrm{Yb}_{\mathrm{N}} / \mathrm{Gd}_{\mathrm{N}}=0.06-1.28\right)$. This analysis also has lower $\mathrm{Y}$ concentration $(37.5 \mathrm{ppm})$ compared to the other zircon in this sample. These zircon grains all have negative Eu anomalies $\left(\mathrm{Eu} / \mathrm{Eu}^{*}=0.04-0.25\right)(\mathrm{Fig} .7 \mathrm{~h})$. The one rim analysed has a similar M-HREE

This article is protected by copyright. All rights reserved. 
slope to the recrystallized zircon $\left(\mathrm{Yb}_{\mathrm{N}} / \mathrm{Gd}_{\mathrm{N}}=0.39\right)$ and a similar Eu anomaly compared to the recrystallized zircon $\left(\mathrm{Eu} / \mathrm{Eu}^{*}=0.29\right)$.

\section{Garnet}

Garnet-biotite gneiss (111-004K). Type-1 garnet cores show a negative M-HREE slope $\left(\mathrm{Yb}_{\mathrm{N}} / \mathrm{Gd}_{\mathrm{N}}=0.53-0.91\right)$ on a chondrite-normalised plot with Eu anomalies yielding $\mathrm{Eu} / \mathrm{Eu}^{*}$ values $=(0.001-0.002)($ Fig. 7i). The rims show a similar M-HREE slope on a chondrite-normalised plot $\left(\mathrm{Yb}_{\mathrm{N}} / \mathrm{Gd}_{\mathrm{N}}=0.58-0.84\right)$, with a less pronounced Eu anomaly $\left(\mathrm{Eu} / \mathrm{Eu}^{*}=0.005\right)$ and relative enrichment in M-HREE compared to the cores (Fig 7i).

Type-2 garnet shows limited core to rim variation and has a near flat M-HREE slope on a chondrite-normalised plot with $\mathrm{Yb}_{\mathrm{N}} / \mathrm{Gd}_{\mathrm{N}}$ values of $0.06-0.12$ for cores and slightly steeper slopes of $0.17-0.23$ for the rims. The Eu anomaly is in the cores covers a range of values that includes the rims with $\mathrm{Eu} / \mathrm{Eu}^{*}$ values of $0.0005-0.010$ in the cores and 0.001-0.004 in the rims (Fig 7i).

Transition zone (I11-004C). Garnet cores display a flat M-HREE slope on a chondritenormalised plot $\left(\mathrm{Yb}_{\mathrm{N}} / \mathrm{Gd}_{\mathrm{N}}=0.31-0.44\right)$ with the rims showing a negative M-HREE slope $\left(\mathrm{Yb}_{\mathrm{N}} / \mathrm{Gd}_{\mathrm{N}}=0.012-0.038\right)$ (Fig. $\left.7 \mathrm{j}\right)$. There is more variation in Eu anomaly in the cores compared to the rims with $\mathrm{Eu} / \mathrm{Eu}^{*}$ values of $0.002-0.005$ and 0.005 respectively.

Charnockite (I11-008C). The cores and rims of garnet from the charnockite shows slightly negative to flat M-HREE slopes on a chondrite-normalised plot $\left(\mathrm{Yb}_{\mathrm{N}} / \mathrm{Gd}_{\mathrm{N}}=\right.$ $0.43-1.19$ and $0.44-1.35$ respectively) and $\mathrm{Eu} / \mathrm{Eu}^{*}$ of $0.002-0.006$ for cores and $0.001-$ 0.005 for rims (Fig. $7 \mathrm{k}$ ).

Metapelitic gneiss (TB-14-025). Type-1 garnet cores and rims show a negative M-HREE slope $\left(\mathrm{Yb}_{\mathrm{N}} / \mathrm{Gd}_{\mathrm{N}}=0.042-0.13\right.$ and $0.043-0.091$ respectively) with the majority of core analyses at higher HREE concentrations (Fig. 7l). The cores show a higher degree of scatter in the HREE than the rims. There is little variation in $\mathrm{Eu}$ anomaly between cores and rims in these garnet grains $\left(\mathrm{Eu} / \mathrm{Eu}^{*}\right.$ values of 0.005-0.008 and 0.005-0.011 respectively).

Type-2 garnet core and rims show similar near flat to slightly negative M-HREE slopes with $\mathrm{Yb}_{\mathrm{N}} / \mathrm{Gd}_{\mathrm{N}}$ values of $0.175-0.363$ and $0.173-0.457$ respectively (Fig. $7 \mathrm{l}$ ). Both cores and rims show a spread in HREE concentrations but the rims show more scatter. There is little variation in Eu anomaly between the cores and rims in these garnets $\left(\mathrm{Eu} / \mathrm{Eu}^{*}=0.005-0.007\right.$ and 0.004-0.006 respectively).

\section{DISCUSSION}

\section{Pressure-temperature evolution}

As all of the studied samples were collected from the same locality and no major structural discontinuities were observed that could have led to the juxtaposition of units with different tectonic histories, it is assumed all rocks share a common $P-T-t$ history. We have modelled this history using pseudosections calculated in the NCKFMASHTO system, which can successfully account for all observed peak minerals with the exception of biotite and spinel. Small quantities of biotite are interpreted as part of the peak assemblage in both the metapelitic gneiss and the garnet-biotite gneiss (Fig. 3a,i), but biotite is likely to be stable at temperatures higher than those predicted

This article is protected by copyright. All rights reserved. 
in the NCKFMASHTO system due to additional components, in particular fluorine, which has been reported in incipient charnockites and associated rock types from southern India (Chacko et al., 1987; Stähle et al., 1987; Nair \& Chacko, 2002; Santosh et al., 2003a; Ravindra Kumar, 2004). For this reason, both biotite-bearing and biotite-absent fields have been included in the inferred peak $P-T$ conditions for the garnet-biotite and metapelitic gneisses. Spinel within the metapelitic gneiss is only stable within only the quartz-free melanosome and has been excluded from the inferred peak assemblage in the modelled pseudosection as this was calculated for a bulk composition that contains both melanosome and leucosome causing quartz to be predicted across the whole modelled interval.

This pseudosection modelling predicts that peak assemblages in the three main rock types at Kakkod have $P-T$ stability fields of 4.6 to $>10 \mathrm{kbar}$ and $790-940{ }^{\circ} \mathrm{C}$ (garnet-biotite gneiss, Fig. 5a), 4.9-9.0 kbar and 820-960 ${ }^{\circ} \mathrm{C}$ (garnet-bearing charnockite, Fig. 5b) and 5.6 to $>10 \mathrm{kbar}, 740{ }^{\circ} \mathrm{C}$ to $>960{ }^{\circ} \mathrm{C}$ (metapelitic gneiss Fig. 5c). While these fields are different, there is a region of overlap (highlighted in Fig. 8) suggesting peak conditions of 6-9 kbar $830-925^{\circ} \mathrm{C}$. Such conditions are consistent with many peak $P-T$ estimates from elsewhere in the Trivandrum block (Chacko et al., 1987; Santosh, 1987; Nandakumar \& Harley, 2000; Pattison et al., 2003; Collins et al., 2014). On this basis we infer that mineral assemblages in the garnet-biotite gneiss, charnockite and metapelitic gneiss were stabilised at similar $P-T$ conditions.

The metapelitic gneiss is best suited to constrain the $P-T$ path at Kakkod as it contains a relatively low-variance mineral assemblage compared to the other samples and is a fairly typical (albeit residual) aluminous metapelite. However, due to the effects of melt loss, the calculated pseudosections based on residual compositions are not suitable for accurately constraining the prograde path (White \& Powell, 2002; Diener et al., 2013) and therefore we focus here on the retrograde evolution. The growth of cordierite and biotite in the metapelite is interpreted to record high-temperature retrograde decompression to around 6.5-5.5 kbar followed by cooling (Fig. 8). The lack of orthopyroxene in this sample suggests that pressures did not drop below $\sim 5 \mathrm{kbar}$ (Fig. 5c), and this is also consistent with the lack of orthopyroxene in the garnet-biotite gneiss (Fig.5a). This evolution is likely to be part of a clockwise $P-T$ path and is similar to many paths reported from other areas in southern India (Nandakumar \& Harley, 2000; Shabeer et al., 2002; Cenki et al., 2004; Collins et al., 2014; Clark et al., 2015; Johnson et al., 2015). It is important to note that all three samples can be modelled with a single $P-T$ path, although the $P-T$ path suggested in Fig. 8 , which shows decompression from $\sim 8$ to $\sim 6 \mathrm{kbar}$, is not a unique solution (for example a path with a smaller pressure decrease from $\sim 7$ to 6 kbar could also explain the observed assemblages).

Our findings that mineral assemblages in all three main rock types at Kakkod are stable at similar $P-T$ conditions conflict with the conclusions of Endo et al. (2013), who argued that the metapelitic gneiss preserves evidence for higher-grade conditions than the garnet-biotite gneiss and charnockite. However, while Endo et al. (2013) used $P-T$ pseudosections to derive estimates for peak metamorphic conditions in garnet-biotite gneiss and charnockite, they were unable to use this approach for the metapelite because this rock type was not exposed in the quarry that they studied. Instead they relied on the earlier study of Tadokoro et al. (2008) who used Zn-in-spinel barometry 
and feldspar-solvus thermometry to propose peak $P-T$ conditions of $10-12 \mathrm{kbar}$ and $900-1000^{\circ} \mathrm{C}$ for the Trivandrum Block metapelite. Tadokoro et al. (2008) provided only very brief descriptions of mineral-chemical relationships in their samples, and little information on how they selected mineral compositions for conventional thermobarometry, which makes it difficult to evaluate their $P-T$ estimates. However, our results allow for a simpler and more consistent interpretation of metamorphic $P-T$ conditions in the Trivandrum Block, and we therefore prefer a model in which all rocks underwent peak metamorphism and a high- $T$ decompression within a pressure interval of 9-6 kbar.

\section{A case for peak-metamorphic charnockite formation}

As highlighted above, the matrix peak charnockite assemblage containing liquid, garnet, orthopyroxene, ilmenite, K-feldspar, plagioclase and quartz is predicted to be stable at conditions of $820-960{ }^{\circ} \mathrm{C}$ and $\sim 4.9-9.0 \mathrm{kbar}$, and this field overlaps with those inferred for peak metamorphic assemblages in other rock compositions (Fig. 8). Thus it is permissible that the orthopyroxene-bearing charnockite assemblage formed the same time as peak assemblages in the host garnet-biotite gneiss. A similar conclusion was reached by Endo et al. (2013) even though they assumed different peak conditions for the metapelite (as discussed above). Although charnockite stabilisation at the metamorphic peak is our preferred interpretation, the microstructural relationships are ambiguous and orthopyroxene may also have grown during high-temperature retrograde decompression. Mineral isopleths of orthopyroxene (Fig. 8) permit either of these scenarios, and the very low abundance of orthopyroxene in these felsic bulk compositions leads to large uncertainties in both observed and predicted mineral modes.

The modelled stability of orthopyroxene differs significantly between the charnockite and garnet-biotite gneiss (maximum pressure limits of 9 and $5 \mathrm{kbar}$, respectively) and this must reflect a difference in bulk composition between these two rock types. However, these two compositions are very similar (Table 1), making it difficult to precisely determine the components that are controlling orthopyroxene stability at Kakkod. Previous comparisons of incipient charnockite and host garnetbiotite gneiss in the Trivandrum Block have identified small differences in the concentrations of components such as $\mathrm{SiO}_{2}, \mathrm{~K}_{2} \mathrm{O}, \mathrm{Na}_{2} \mathrm{O}, \mathrm{MgO}$ and $\mathrm{FeO} / \mathrm{Fe}_{2} \mathrm{O}_{3}$, but there seems little consistency in the magnitude of these variations or even in which rock has the higher and which the lower concentration (e.g. Hansen et al., 1987; Raith \& Srikantappa, 1993; Endo et al., 2013). A recent study by Endo et al. (2012) of similar rocks further north in the Madurai Block used pseudosection modelling to argue that orthopyroxene in charnockite patches was stabilised by less-oxidised conditions; our study also indicates that ferric iron exhibits a strong control on orthopyroxene stability. In particular, a $\mathrm{P}-\mathrm{M}_{\mathrm{Fe} 2 \mathrm{O} 3}$ pseudosection calculated for the Kakkod charnockite sample indicates that orthopyroxene is stabilised to higher pressures with a small reduction in the ferric/ferrous ratio (Fig. S2). However, our final $P-T$ pseudosections (Fig. 5) were calculated for identical $\mathrm{Fe}_{2} \mathrm{O}_{3}$ concentrations in the charnockite and garnet-biotite gneiss, and marginally higher $\mathrm{Fe}_{2} \mathrm{O}_{3} /\left(\mathrm{Fe}_{2} \mathrm{O}_{3}+\mathrm{FeO}\right)$ values in the charnockite, indicating that ferric iron is not responsible for the differences in orthopyroxene stability in our models.

This article is protected by copyright. All rights reserved. 
The exact compositional variables that control the stability of orthopyroxene between the two rock compositions at Kakkod is not yet known, although we emphasize that the very low abundance of mafic minerals in these highly felsic bulk rock compositions means that their stability will be sensitive to small variations in bulk chemistry. Similarly, it is unclear what might have caused these local compositional variations, with insufficient information available to determine whether they were inherited from the protolith or a result of syn-metamorphic fluid flow.

\section{Timing of peak metamorphism at Kakkod quarry}

Zircon from the garnet-biotite gneiss and charnockite shows oscillatory-zoned cores (Fig. 4b,f) that are interpreted to be inherited from the protolith to the garnet-biotite gneiss. The ages of these inherited cores fall within known ages of inherited Palaeoproterozoic igneous zircon for the Trivandrum Block (Fig. 6b,e) (Collins et al., 2007b, 2014) and show steep M-HREE slopes indicative of growth without garnet (Fig. 7f,g) (Hoskin \& Schaltegger, 2003). A number of monazite grains from the metapelitic gneiss (Fig. 6g) also show older discordant ages (>c. $650 \mathrm{Ma}$ ) and again fall along a discordia with a Palaeoproterozoic upper intercept. These are likewise interpreted to be inherited grains that have undergone Pb-loss during the Late Neoproterozoic Cambrian metamorphic event, and they have the most enriched HREE of any of monazite analyses.

The onset of high-grade metamorphism at Kakkod is interpreted to have occurred at c. 590 Ma based on the oldest metamorphic monazite ages (Fig. 9), an age that is consistent with other studies from the Trivandrum and Nagercoil Blocks (Taylor et al., 2014, Johnson et al., 2015). Monazite cores in the garnet-biotite gneiss, transition zone and metapelitic gneiss are all enriched in HREE suggesting they grew before or during the appearance of a HREE-enriched phase (i.e. c. $590 \mathrm{Ma}$ ) (Fig. 7a-d) (Hermann \& Rubatto, 2003; Rubatto et al., 2006). This HREE-enriched phase is assumed to be garnet, which is present in all samples except the pegmatite. The monazite from the metapelitic gneiss has M-HREE concentrations an order of magnitude larger than the other samples (due to influence of HREE-enriched inherited monazite) and also has a greater spread of HREE contents (Fig. 7d). This scatter in HREE for the non-inherited monazite in the metapelitic gneiss and the few low HREE cores in the garnet-biotite gneiss and the transition zone is interpreted to represent the increasing influence of a HREE phase (i.e. garnet growth) during monazite crystallization.

The type- 1 garnet in both garnet-biotite gneiss and metapelitic gneiss is interpreted to be prograde with slightly negative M-HREE slopes (Hermann \& Rubatto, 2003). The type- 2 garnet from the garnet-biotite and metapelitic gneiss as well as the transition zone and charnockite is interpreted to be peritectic and grew in the presence of zircon based on its near flat M-HREE slope (Hokada \& Harley, 2004). In both the garnet-biotite gneiss and the metapelitic gneiss the rims of type-1 garnet were likely modified by the influx of REE-enriched partial melt, resulting in rim compositions closer to type-2. The population of equant 'soccer ball' metamorphic zircon in the charnockite is interpreted to have precipitated as high-T subsolidus growth (Schaltegger et al., 1999; Harley et al., 2007) at $562 \pm 22$ Ma (Fig. 6f), rather than during post-peak melt crystallization due to their age and sector zoned 'soccer ball' texture (Vavra et al., 1996; Schaltegger et al., 1999; Kelly \& Harley, 2005). The 'soccer ball' zircon is inferred to have equilibrated with the flat-REE garnet in the charnockite, which is equivalent to

This article is protected by copyright. All rights reserved. 
type-2 garnet in other rock types. This is corroborated by the near 1:1 $\mathrm{D}_{\mathrm{REE}}$ (zircon/garnet) ratio between garnet and the 'soccer ball' zircon (Taylor et al., 2015). The garnet rims from the transition zone show HREE concentrations nearly an order of magnitude lower than any of the other samples. These low HREE concentrations are interpreted to reflect the retrograde reaction observed at garnet margins to an intergrowth of biotite and quartz, which is not seen in the other samples. The trend of increasing negative Eu anomaly from core to rim in zircon (garnet-biotite gneiss and charnockite), monazite (garnet-biotite gneiss, metapelitic gneiss) and garnet (garnetbiotite gneiss) could indicate the increasing crystallization of plagioclase likely from partial melt whilst zircon, monazite and garnet was recrystallizing/growing or the presence of plagioclase before recrystallization, sequestering much of the Eu (Johnson et al., 2015). Some samples show little to no differentiation in Eu anomalies between cores and rims.

Rims on inherited zircon from the charnockite contain a number of different ages that potentially relate to (1) partial to full recrystallization during prograde metamorphism and (2) neocrystallization during subsequent melt crystallization (Vavra et al., 1996; Schaltegger et al., 1999; Kelly \& Harley, 2005). The onset of melt crystallization is interpreted to have occurred at c. 540 Ma based on the upper quartile distribution of zircon rim ages from the charnockite (Fig. 9). The majority of zircon crystallized between $c$. 540-510 Ma matching that found in other studies of the Trivandrum Block and adjacent areas (Harley \& Nandakumar, 2014; Taylor et al., 2014; Johnson et al., 2015). The ages calculated for the monazite cores and metamorphic zircon rims define a window of prograde to peak metamorphism of $c$. 50 Ma from the onset at 590 to $540 \mathrm{Ma}$, followed by a further $30 \mathrm{Ma}$ during which melt crystallized (Fig. 9).

The zircon from the metapelitic gneiss shows remnants of oscillatory zoning that has become diffuse through recrystallization (Hoskin \& Black, 2000; Wang et al., 2014). Unlike similar zircon from the garnet-biotite gneiss and charnockite with partly reset pre-metamorphic ages and steep positive M-HREE slopes, this zircon from the metapelitic gneiss gives a concordant c. 550 Ma metamorphic age and mostly has flat HREE patterns interpreted as a result of recrystallization and growth in the presence of garnet (Fig. 7h). The one analysis of recrystallized zircon with low HREE also has the youngest spot age and is interpreted to represent increasing recrystallization with age. Metamorphic zircon rims in all samples are likely a result of post-peak melt crystallization (Roberts \& Finger, 1997; Kelsey et al., 2008). Monazite cores from the pegmatite are interpreted to be inherited from the garnet-biotite gneiss with ages ranging from c. 580-512 Ma (Fig. 9). REE in the pegmatite monazite cores show similar HREE concentrations and M-HREE slope to monazite in the garnet-biotite gneiss (Fig. $7 \mathrm{e}$ ). The ages from the recrystallized areas (weighted mean ${ }^{207} \mathrm{~Pb} /{ }^{235} \mathrm{U}$ age $512 \pm 10 \mathrm{Ma}$ ) are interpreted to represent the emplacement of the pegmatite (Fig. 9).

\section{Age of post-peak fluid event}

Lobate high-Th recrystallized zones in monazite grains (Fig. 4; Table 2) are interpreted to be the result of coupled dissolution-reprecipitation. These textures are similar to those observed in previous experimental and empirical studies (Harlov \& Hetherington, 2010; Harlov et al., 2011; Williams et al., 2011; Kelly et al., 2012), and based on comparisons with the experiments Taylor et al. (2014) interpreted the same features in

This article is protected by copyright. All rights reserved. 
incipient charnockites at the nearby locality of Kottavattom to have formed during postpeak influx of hydrous alkali-rich fluid.

Monazite ages from the Kakkod samples show variable amounts of resetting (Pbloss) with some grains showing distinct sections (lobate dissolution-reprecipitation structures) that are variably reset, and others with no internal structures at all that are fully reset, recording the youngest ages of any of the samples. The effects of incomplete $\mathrm{Pb}$-loss manifests itself as the presence of discordant monazite ages within the metapelitic gneiss (Fig. 6g) and the large spread of ages along concordia to a younger age. Similar manifestations of Pb-loss can occur in zircon from prolonged high- $T$ localities like the Rayner Complex in Antarctica (Halpin et al., 2012). This spread is particularly well developed in the monazite analyses from the garnet-biotite gneiss and metapelitic gneiss (Fig. 6a,d,e). This spread along concordia records a range of ages from c. $590 \mathrm{Ma}$ to around c. $490 \mathrm{Ma}$. Samples that record the large spread in ages all contain fluid-related coupled dissolution-reprecipitation textures in the monazite (Fig. $4 \mathrm{a}, \mathrm{d}, \mathrm{e})$. From our data the transition zone monazite appears to have seen the least overprint with limited smearing along concordia, and also shows coupled dissolutionreprecipitation textures. Monazite from the charnockite has no internal structures and recorded the youngest ages of any of the samples. We suggest that this represents complete resetting of the monazite in the charnockite, with partially reset monazite from the other samples smearing down concordia towards this same age. The significance of this apparently greater degree of fluid-driven monazite resetting in the charnockite is unclear, not least because only two monazite grains were found in the single sample of charnockite analysed in this study, and more analyses of more samples would be needed to establish if the charnockite monazite truly saw more resetting than monazite in other rock types.

The monazite recrystallized zones in the garnet-biotite gneiss, metapelitic gneiss and transition zone show large variations in HREE, with consistently lower concentrations compared to their respective cores (Fig. 7a,b,d). This is interpreted to represent the modification of monazite in the presence of garnet, after this latter phase had sequestered HREE.

Ages of c. 525-490 Ma for the monazite population in the charnockite and the youngest monazite recrystallized zones from the transition zone, garnet-biotite gneiss, and metapelitic gneiss are interpreted as the time of fluid infiltration and coupled dissolution-reprecipitation of monazite (Fig. 9). Based on the overlap between the inferred ages of melt crystallization ( 540-510 Ma) and hydrous fluid influx ( 525$490 \mathrm{Ma}$ ), and the presence of the pegmatite dyke that cuts across the garnet-biotite gneiss, we suggest that the fluids were sourced from a local melt system, perhaps at deeper crustal levels, that crystallized slightly later than melt in the Kakkod samples. This is similar to the source of fluids proposed by Taylor et al. (2014). The presence of the coupled dissolution-reprecipitation textures within monazite from the garnetbiotite gneiss, transition zone, metapelitic gneiss as well as the homogenous charnockite monazite indicate that fluid influx was pervasive throughout the whole outcrop which reinforces the study by Taylor et al. (2014).

This article is protected by copyright. All rights reserved. 


\section{CONCLUSIONS}

- Phase relationships in all three rock types at Kakkod (garnet-biotite gneiss, charnockite, and metapelitic gneiss) are consistent with peak metamorphic conditions of $c .830-925^{\circ} \mathrm{C}$ and $6-9$ kbar.

- Peak metamorphism was followed by high-temperature decompression best recorded by retrograde growth of cordierite and/or biotite in the metapelitic gneiss.

- The onset of high-grade metamorphism is dated at c. 590 Ma with melt crystallization starting at c. 540 Ma. The majority of zircon grew at 540-510 Ma, which is taken as when most of the melt at Kakkod crystallized.

- Orthopyroxene-bearing charnockite assemblages replaced local patches of the garnet-biotite gneiss at or soon after peak metamorphism. They must reflect local compositional heterogeneities in the garnet-biotite gneiss, although we cannot determine if these heterogeneities were inherited from the protolith or introduced by high-temperature fluid influx.

- $T-P-X$ sections highlight the sensitivity of orthopyroxene stability in metafelsic rocks to the local oxidation state, but this does not seem to have been the controlling factor in charnockite formation at Kakkod.

- Later lower-temperature fluid influx at c. 525-490 Ma led to coupled dissolutionreprecipitation of monazite and variable resetting of its $\mathrm{U}-\mathrm{Pb}$ isotope system. Based on comparisons with monazite textures in experiments, we follow Taylor et al. (2014) in suggesting that these fluids were aqueous and perhaps rich in alkalis.

- The presence of coupled dissolution-reprecipitation textures in monazite from all samples at Kakkod indicates that late fluid flux was pervasive throughout the outcrop. It is likely to have driven hydrous retrogression of the charnockite, but played no role in its stabilization.

- The timing of monazite modification at Kakkod is very close to final melt crystallization ages from this and other localities. This suggests that fluid influx was linked to cooling and solidification of local (and possibly deeper) melt systems, and could be related to the pegmatite dyke at Kakkod with a crystallization age of $\sim 512 \mathrm{Ma}$.

\section{ACKNOWELDGEMENTS}

Zircon and monazite U-Pb analyses were carried out using the SHRIMP II Ion Microprobe at the John de Laeter Centre for Isotope Research, Perth, managed by A. Kennedy. LA-ICP-MS REE analyses were carried out at the GeoHistory Facility, John de Laeter Centre, Curtin University. Financial support for this project was provided by an ARC DECRA fellowship to CC and ARC Discovery Project Grant DP150102773 to ICWF and CC. We thank J. Halpin, S. Harley and N. Daczko for their thorough reviews and G. Clarke for his editorial handling.

\section{REFERENCES}

Anders, E. \& Grevesse, N., 1989. Abundances of the elements: Meteoric and solar. Geochimica et Cosmochimica Acta, 53, 197-214.

Black, L. P., Kamo, S. L., Allen, C. M. et al., 2003. TEMORA 1: a new zircon standard for Phanerozoic U-Pb geochronology. Chemical Geology, 200, 155-170.

Braun, I., 2006. Pan-African granitic magmatism in the Kerala Khondalite Belt, southern India. Journal of Asian Earth Sciences, 28, 38-45.

This article is protected by copyright. All rights reserved. 
Braun, I., Montel, J.-M. \& Nicollet, C., 1998. Electron microprobe dating of monazites from high-grade gneisses and pegmatites of the Kerala Khondalite Belt, southern India. Chemical Geology including Isotope Geoscience, 146, 65-68.

Buick, I. S., Clark, C., Rubatto, D., Hermann, J., Pandit, M. \& Hand, M., 2010. Constraints on the Proterozoic evolution of the Aravalli-Delhi Orogenic belt (NW India) from monazite geochronology and mineral trace element geochemistry. Lithos, 120, 511-528.

Cenki, B., Braun, I. \& Bröcker, M., 2004. Evolution of the continental crust in the Kerala Khondalite Belt, southernmost India: evidence from $\mathrm{Nd}$ isotope mapping, $\mathrm{U}-\mathrm{Pb}$ and Rb-Sr geochronology. Precambrian Research, 134, 275-292.

Chacko, T., Lamb, M. \& Farquhar, J., 1996. Ultra-high temperature metamorphism in the Kerala Khondalite Belt. Gondwana Research Group Memoir, 3, 157-165.

Chacko, T., Ravindra Kumar, G. R., Meen, J. K. \& Rodgers, J.W., 1992. Geochemistry of high-grade supracrustal rocks from the Kerala Khondalite Belt and adjacent massif charnockites, South India. Precambrian Research, 55, 469-489.

Chacko, T., Ravindra Kumar, G. R. \& Newton, R. C., 1987. Metamorphic P-T conditions of the Kerala (South India) Khondalite Belt, a granulite facies supracrustal terrain. The Journal of Geology, 95(3), 343-358.

Chetty, T. R. K., Fitzsimons, I. C. W., Brown, L., Dimri, V. P. \& Santosh, M., 2006. Crustal structure and tectonic evolution of the Southern Granulite Terrane, India: introduction. Gondwana Research, 10, 3-5.

Clark, C., Collins, A. S., Santosh, M., Taylor, R. \& Wade, B. P., 2009a. The P-T-t architecture of a Gondwanan suture: REE, U-Pb and Ti-in-zircon thermometric constraints from the Palghat Cauvery shear system, South India. Precambrian Research, 174, 129-144.

Clark, C., Collins, A. S., Timms, N. E., Kinny, P., Chetty, T. R. K. \& Santosh, M., 2009b. SHRIMP U-Pb age constraints on magmatism and high-grade metamorphism in the Salem Block, southern India. Gondwana Research, 16, 27-36.

Clark, C., Healy, D., Johnson, T., Collins, A. S., Taylor, R., Santosh, M. \& Timms, N. E., 2015. Hot orogens and supercontinent amalgamation: A Gondwanan example from southern India. Gondwana Research, XX, XX.

Collins, A. S., Clark, C. \& Plavsa, D., 2014. Peninsula India in Gondwana: the tectonothermal evolution of the Southern Granulite Terrain and its Gondwanan counterparts. Gondwana Research.

Collins, A. S., Clark, C., Sajeev, K., Santosh, M., Kelsey, D. E. \& Hand, M., 2007a. Passage through India: the Mozambique Ocean suture, high-pressure granulites and the Palghat-Cauvery shear zone system. Terra Nova, 19, 141-147.

Collins, A. S. \& Pisarevsky, S. A., 2005. Amalgamating eastern Gondwana: the evolution of the Circum-Indian Orogens. Earth-Science Reviews, 71, 229-270.

Collins, A. S., Santosh, M., Braun, I. \& Clark, C., 2007b. Age and sedimentary provenance of the Southern Granulites, South India: U-Th-Pb SHRIMP secondary ion mass spectrometry. Precambrian Research, 155, 125-138.

de Laeter, J. R. \& Kennedy, A. K., 1998. A double focussing mass spectrometer for geochronology. International Journal of Mass Spectrometry, 178, 43-50.

Diener, J. F. A. \& Powell, R., 2010. Influence of ferric iron on the stability of mineral assemblages. Journal of Metamorphic Geology, 28, 599-613.

Diener, J. F. A., White, R. W., Link, K., Dreyer, T. S. \& Moodley, A., 2013. Clockwise, low-P metamorphism of the Aus granulite terrain, southern Namibi, during the Mesoproterozoic Namaqua Orogeny. Precambrian Research, 224, 629-652.

This article is protected by copyright. All rights reserved. 
Drury, S. A., Harris, N. B. W., Holt, R. W., Reeves-Smith, G. J. \& Wightman, R. T., 1984. Precambrian Tectonics and Crustal Evolution in South India. The Journal of Geology, 92, 3-20.

Endo, T., Toshiaki, T., Santosh, M. \& Shaji, E., 2012. Phase equilibrium modeling of incipient charnockite formation in NCKFMASHTO and MnNCKFMASHTO systems: A case study from Rajapalaiyam, Madurai Block, southern India. Geoscience Frontiers, 3, 801-812.

Endo, T., Toshiaki, T., Santosh, M., Shimizu, Hisako \& Shaji, E., 2013. Granulite formation in a Gondwana fragment: petrology and mineral equilibrium modeling of incipient charnockite from Mavadi, southern India. Mineralogy and Petrology, 112.

Fonarev, V. I., Konilov, A. N. \& Santosh, M., 2000. Multistage metamorphic evolution of the Trivandrum Granulite Block, Southern India. Gondwana Research, 3, 293-314.

Fyfe, W. S., 1973. The granulite facies, partial melting and the Archaean crust. Phiosophical Transactions of the Royal Society of London. Series A, Mathematical and Physical Sciences, 273(1235), 457-461.

Halpin, J. A., Daczko, N. R., Milan, L. A. \& Clarke, G. L., 2012. Decoding near-concordant $\mathrm{U}-\mathrm{Pb}$ zircon ages spanning several hundred million years: recrystallisation, metamictisation or diffusion? Contributions to Mineralogy and Petrology, 163, 67-85.

Hansen, E. C., Janardhan, A. S., Newton, R. C., Prame, W. K. B. N. \& Kumar, G. R. R., 1987. Arrested charnockite formation in southern India and Sri Lanka. Contributions to Mineralogy and Petrology, 96, 225-244.

Harley, S. L., Kelly, N. M. \& Möller, A., 2007. Zircon behaviour and the thermal histories of mountain chains. Elements, 3, 25-30.

Harley, S. L. \& Nandakumar, V., 2014. Accessory mineral behaviour in granulite migmatites: a case study from the Kerala Khondalite Belt, India. Journal of Petrology, 55, 1965-2002.

Harley, S. L. \& Santosh, M., 1995. Wollastonite at Nuliyam, Kerala, souterhn India: a reassessment of $\mathrm{CO}_{2}$-infiltration and charnockite formation at a classic locality. Contributions to Mineralogy and Petrology, 120, 83-94.

Harlov, D. E. \& Hetherington, C. J., 2010. Partial high-grade alteration of monazite using alkali-bearing fluids: Experiment and nature. American Mineralogist, 95, 11051108.

Harlov, D. E., Wirth, R. \& Hetherington, C. J., 2011. Fluid-mediate partial alteration in monazite: the role of coupled dissolution-reprecipitation in element redistribution and mass transfer. Contributions to Mineralogy and Petrology, 162, 329-348.

Harris, N. B. W., Santosh, M. \& Taylor, P. N., 1994. Crustal evolution in South India: constraints from Nd isotopes. The Journal of Geology, 102, 139-150.

Hermann, J. \& Rubatto, D., 2003. Relating zircon and monazite domains to garnet growth zones: age and duration of granulite facies metamorphism in the Val Malenco lower crust. Journal of Metamorphic Geology, 21, 833-852.

Hokada, T. \& Harley, S. L., 2004. Zircon growth in UHT leucosome: constraints from zircon-garnet rare earth elements (REE) relations in Napier Complex, East Antarctica. Journal of Mineralogical and Petrological Sciences, 99, 180-190.

Holland, T. J. B. \& Powell, R., 2011. An improved and extended internally consistent thermodynamic dataset for phases of petrological interest, involving a new equation of state for solids. Journal of Metamorphic Geology, 29, 333-383.

This article is protected by copyright. All rights reserved. 
Hoskin, P. W. O. \& Black, L. P., 2000. Metamorphic zircon formation by solid-state recrystallization of protolith igneous zircon. Journal of Metamorphic Geology, 18, 423-439.

Hoskin, P. W. O. \& Schaltegger, U., 2003. The composition of zircon and igneous and metamorphic petrogenesis. Reviews in mineralogy and geochemistry, 53, 27-62.

Jackson, D. H. \& Santosh, M., 1992. Dehydration reaction and isotope front transport induced by $\mathrm{CO}_{2}$ infiltration at Nuliyam, South India. Journal of Metamorphic Geology, 10, 365-382.

Johnson, T., Clark, C., Taylor, R., Santosh, M. \& Collins, A. S., 2015. Prograde and retrograde growth of monazite in migmatites: An example from the Nagercoil Block, southern India. Geoscience Frontiers, 6, 373-387.

Kelly, N. M. \& Harley, S. L., 2005. An integrated microtextural and chemical approach to zircon geochronology: refining the Archaean history of the Napier Complex, east Antartica. Contributions to Mineralogy and Petrology, 149, 57-84.

Kelly, N. M., Harley, S. L. \& Möller, A., 2012. Complexity in the behavior and recrystallization of monazite during high-T metamorphism and fluid infiltration. Chemical Geology, 322-323, 192-208.

Kelsey, D. E., Clark, C. \& Hand, M., 2008. Thermobarometric modelling of zircon and monazite growth in melt-bearing systems: examples using model metapelitic and metapsammitic granulites. Journal of Metamorphic Geology, 26, 199-212.

Kennedy, A. K. \& de Laeter, J. R., 1994. The performance characteristics of the WA SHRIMP II ion microprobe. US Geological survey circular, 1107, 166.

Kirkland, C. L., Whitehouse, M. J. \& Slagstad, T., 2009. Fluid-assisted zircon and monazite growth within a shear zone: a case study from Finnmark, Arctic Norway. Contributions to Mineralogy and Petrology, 158, 637-657.

Korhonen, F. J., Saw, A. K., Clark, C., Brown, M. \& Bhattacharya, S., 2011. New constraints on UHT metamorphism in the Eastern Ghats Province through the application of phase equilibria modelling and in situ geochronology. Gondwana Research, 20, 764-781.

Kretz, R., 1983. Symbols for rock-forming minerals. American Mineralogist, 68, 277-279.

Kröner, A., Santosh, M., Hegner, E. et al., 2015. Palaeoproterozoic ancestry of PanAfrican high-grade granitoids in southernmost India: Implications for Gondwana reconstructions. Gondwana Research, 27, 1-37.

Ludwig, K. R., 2003. Isoplot 3.0. A Geochronological Toolkit for Microsoft Excel. Berkeley Geochronological Center Special Publication 2, 4, 70.

Ludwig, K. R., 2009. SQUID II.. a user's manual. Berkeley Geochronological Center Special Publication 2.

Morimoto, T., Santosh, M., Tsunogae, T. \& Yoshimura, Y., 2004. Spinel+Quartz association from the Kerala Khondalites, southern India: evidence for ultra-high temperature metamorphism. Journal of Mineralogical and Petrological Sciences, 99, 257-278.

Nair, R. \& Chacko, T., 2002. Fluid-absent melting of high-grade semi-pelites: P-T constraints on orthopyroxene formation and implications for granulite genesis. Journal of Petrology, 43, 2121-2142.

Nandakumar, V. \& Harley, S. L., 2000. A reappraisal of the pressure-temperature path of granulites from the Kerala Khondalite Belt, southern India. The Journal of Geology, 108, 687-703.

Newton, R. C., 1989. Metamorphic fluids in the deep crust. Annual Review of Earth and Planetary Sciences, 17, 385-412.

This article is protected by copyright. All rights reserved. 
Newton, R. C., 1992. Charnockitic alteration: evidence for $\mathrm{CO}_{2}$ infiltration in granulite facies metamorphism. Journal of Metamorphic Geology, 10, 383-400.

Newton, R. C., Smith, J. V. \& Windley, B. F., 1980. Carbonic metamorphism, granulites and crustal growth. Nature, 288, 45-50.

Newton, R. C. \& Tsunogae, T., 2014. Incipient charnockite: characterization at the type localities. Precambrian Research, 253, 38-49.

Paton, C., Hellstrom, J., Paul, B., Woodhead, J. \& Hergt, J., 2011. Iolite: freeware for the visualisation and processing of mass spectrometric data. Journal of Analytical Atomic Spectrometry, 26, 2508-2518.

Paton, C., Woodhead, J., Hellstrom, J., Hergt, J., Greig, A. \& Maas, R., 2010. Improved laser ablation $\mathrm{U}-\mathrm{Pb}$ zircon and geochronology through robust downhole fractionation correction. Geochemistry, Geophysics, Geosystems, 11.

Pattison, D. R. M., Chacko, T., Farquhar, J. \& McFarlane, R. M., 2003. Temperature of granulite-facies metamorphism: constraints from experimental phase equilibria and thermobarometry corrected for retrograde exchange. Journal of Petrology, 44, 867-900.

Perchuk, L. L., Safonov, O. G., Gerya, T. V., Fu, B. \& Harlov, D. E., 2000. Mobility of components in metasomatic transformation and partial melting of gneisses: an example from Sri Lanka. Contributions to Mineralogy and Petrology, 140, 212232.

Plavsa, D., Collins, A. S., Foden, J. F., Kropinski, L., Santosh, M., Chetty, T. R. K. \& Clark, C., 2012. Delineating crustal domains in Peninsular India: Age and chemistry of orthopyroxene-bearing felsic gneisses in the Madurai Block. Precambrian Research, 198-199, 77-93.

Plavsa, D., Collins, A. S., Payne, J. L., Foden, J. D., Clark, C. \& Santosh, M., 2014. Detrital zircons in basement metasedimentary protoliths unveil the origins of southern India. Bulletin of the Geological Society of America, 126, 791-812.

Raith, M. \& Srikantappa, C., 1993. Arrested charnockite formation at Kottavattam, southern India. Journal of Metamorphic Geology, 11, 815-832.

Raith, M., Srikantappa, C., Ashamanjari, K. G. \& Spiering, B., 1990. The granulite terrane of the Nilgiri Hills (Southern India): characterization of high-grade metamorphism. In: Granulites and Crustal Evolution, pp. 339-365, Springer Netherlands.

Rajesh, H. M. \& Santosh, M., 2004. Charnockite magmatism in southern India. Proceedings of the Indian Academy of Sciences. A Earth and Planetary Sciences, 113, 565-585.

Rajesh, H. M. \& Santosh, M., 2012. Charnockites and charnockites. Geoscience Frontiers, 3, 1-8.

Ravindra Kumar, G. R., 2004. Mechanism of arrested charnockite formation at Nemmara, Palghat region, southern India. Lithos, 75, 331-358.

Ravindra Kumar, G. R., Srikantappa, C. \& Hansen, E. C., 1985. Charnockite formation at Ponmudi in southern India. Nature, 313, 207-209.

Roberts, M. P. \& Finger, F., 1997. Do U-Pb zircon ages from granulites reflect peak metamorphic conditions? Geology, 25, 319-322.

Rubatto, D., Hermann, J. \& Buick, I. S., 2006. Temperature and bulk composition contrl on the growth of monazite and zircon during low-pressure anatexis (Mount Stafford, Central Australia). Journal of Petrology, 47, 1973-1996.

This article is protected by copyright. All rights reserved. 
Sacks, P. E., Nambiar, C. G. \& Walters, L. J., 1997. Dextral Pan - African Shear along the Southwestern Edge of the Achankovil Shear Belt, South India: Constraints on Gondwana Reconstructions. The Journal of Geology, 105, 275-284.

Santosh, M., 1987. Cordierite gneisses of southern Kerala, India: petrology, fluid inclusions and implications for crustal uplift history. Contributions to Mineralogy and Petrology, 96, 343-356.

Santosh, M., Maruyama, S. \& Sato, K., 2009. Anatomy of a Cambrian suture in Gondwana: Pacific-type orogeny in southern India. Gondwana Research, 16, 321-341.

Santosh, M. \& Omori, S., 2008. $\mathrm{CO}_{2}$ flushing: A plate tectonic perspective. Gondwana Research, 13, 86-102.

Santosh, M., Tagawa, M., Taguchi, S. \& Yoshikura, S., 2003a. The Nagercoil Granulite Block, southern India: petrology, fluid inclusions and exhumation history. Journal of Asian Earth Sciences, 22, 131-155.

Santosh, M., Yang, Q. Y., Shaji, E., Mohan, M. R., Tsunogae, T. \& Satyanarayanan, M., 2016. Oldest rocks from Peninsular India: evidence for Hadean to Neoarchean crustal evolution. Gondwana Research, 29, 105-135.

Santosh, M., Yang, Q. Y., Shaji, E., Tsunogae, T., Mohan, M. R. \& Satyanarayanan, M., 2015. An exotic Mesoarchean microcontinent: the Coorg Block, southern India. Gondwana Research, 27, 165-195.

Santosh, M., Yokoyama, K., Biju-Sekhar, S. \& Rogers, J. J. W., 2003b. Multiple tectonothermal events in the granulite blocks of southern India revealed from EPMA dating: implications on the history of supercontinents. Gondwana Research, 6, 29-63.

Schaltegger, U., Fanning, C. M., Günther, D., Maurin, J. C., Schulmann, K. \& Gebauer, D., 1999. Growth, annealing and recrystallization of zircon and preservation of monazite in high-grade metamorphism: conventional and in-situ U-Pb isotope, cathodoluminesecence and microchemical evidence. Contributions to Mineralogy and Petrology, 134, 186-201.

Shabeer, K. P., Sajeev, K., Okudaira, T. \& Santosh, M., 2002. Two-stage spinel growth in the high-grade metapelites of the central Kerala Khondalite Belt: implications for prograde P-T path. Journal of Geosciences, Osaka City University, 45(3), 29-43.

Shabeer, K. P., Santish-Kumar, M., Armstrong, R. \& Buick, I. S., 2005. Constraints on the timing of Pan-African granulite-facies metamorphism in the Kerala Khondalite Belt of southern India: SHRIMP mineral ages and Nd isotopic systematics. The Journal of Geology, 113, 95-106.

Spencer, C. J., Kirkland, C. L. \& Taylor, R. J. M., 2015. Strategies toward statistically robust interpretations of in situ $\mathrm{U}-\mathrm{Pb}$ zircon geochronology. Geoscience Frontiers, In press.

Srikantappa, C., Raith, M. \& Spiering, B., 1985. Progressive charnockitization of a leptynite-khondalite suite in southern Kerala, India-evidence for formation of charnockites through decrease in fluid pressure? Journal of the Geological Society of India, 26.

Stacey, J. S. \& Kramers, J. D., 1975. Approximation of terrestrial lead isotope evolution by a two-stage model. Earth and Planetary Science Letters, 26, 207-221.

Stähle, H. J., Raith, M., Hoernes, S. \& Delfs, A., 1987. Element mobility during incipient granulite formation at Kabbaldurga, Southern India. Journal of Petrology, 28, 803-834.

This article is protected by copyright. All rights reserved. 
Stern, R. S. \& Amelin, Y., 2003. Assessment of errors in SIMS zircon U-Pb geochronology using a natural zircon standard and NIST SRM 610 glass. Chemical Geology, 197, 111-142.

Tadokoro, H., Tsunogae, T. \& Santosh, M., 2008. Metamorphic P-T path of eastern Trivandrum Granulite Block, southern India: implications for regional correlation of lower crustal fragments. Journal of Mineralogical and Petrological Sciences, 103, 279-284.

Taylor, R., Clark, C., Fitzsimons, I. C. W., Santosh, M., Hand, M., Evans, N. \& McDonald, B., 2014. Post-peak, fluid-mediated modification of granulite facies zircon and monazite in the Trivandrum Block, southern India. Contributions to Mineralogy and Petrology, 168, 1-17.

Taylor, R., Harley, S. L., Hinton, R. W., Elphick, S., Clark, C. \& Kelly, N. M., 2015. Experimental determination of REE partition coefficients between zircon, garnet and melt: a key to understanding high-T crustal processes. Journal of Metamorphic Geology, 33, 231-248.

Touret, J. L. R. \& Huizenga, Jan Marten, 2012. Charnockite microstructures: From magmatic to metamorphic. Geoscience Frontiers, 3, 1-9.

Vavra, G., Gebauer, D., Schmid, R. \& Compston, W., 1996. Multiple zircon growth and recrystallization during polyphase Late Carboniferous to Triassic metamorphism in granulites of the Ivrea Zone (Southern Alps): an ion microprobe (SHRIMP) study. Contributions to Mineralogy and Petrology, 122, 337-358.

Wang, W., Dunkley, E., Clarke, G. L. \& Daczko, N. R., 2014. The evolution of zircon during low-P partial melting of metapelitic rocks: theoretical predictions and a case study from Mt Stafford, central Australia. Journal of Metamorphic Geology, 32, 791-808.

White, R. W. \& Powell, R., 2002. Melt loss and the preservation of granulite facies mineral assemblages. Journal of Metamorphic Geology, 20, 621-632.

White, R. W., Powell, R., Holland, T. J. B., Johnson, T. \& Green, E. C. R., 2014a. New mineral activity-composition relations for thermodynamic calculations in metapelitic systems. Journal of Metamorphic Geology, 32, 261-286.

White, R. W., Powell, R. \& Johnson, T., 2014b. The effect of Mn on mineral stability in metapelites revisited: new a-x relations for manganese-bearing minerals. Journal of Metamorphic Geology, 32, 809-828.

Whitney, D. L. \& Evans, B. W., 2010. Abbreviations for names of rock-forming minerals. American Mineralogist, 95, 185-187.

Williams, M. L., Jercinovic, M. J., Harlov, D. E., Budzyń, B. \& Hetherington, C. J., 2011. Resetting monazite ages during fluid-related alteration. Chemical Geology, 283, 218-225.

Yoshida, M., Santosh, M. \& Shirahata, H., 1991. Geochemistry of gneiss-granulite transformation in the "incipient charnockite" zones of southern India. Mineralogy and Petrology, 45, 69-83.

\section{SUPPORTING INFORMATION:}

Fig. S1: Garnet-biotite gneiss $T-X$ pseudosection with varying ferric iron content $(0)$ from the XRF measured value of $0.39(X=0)$ to $0.01(X=1)$. Note that higher $X$ values in this diagram actually correspond to lower $\mathrm{X}_{\mathrm{Fe} 203}$ in the rock. A mid value of $\mathrm{X}=0.7$ (black line) was selected for the final $P-T$ diagram.

This article is protected by copyright. All rights reserved. 
Fig. S2: Charnockite $P-X$ pseudosection with varying ferric iron content $(0)$ from the $\mathrm{XRF}$ measured value of $0.35(\mathrm{X}=0)$ to $0.01(\mathrm{X}=1)$. Note that higher $\mathrm{X}$ values in this diagram actually correspond to lower $\mathrm{X}_{\mathrm{Fe} 203}$ in the rock. A mid value of $\mathrm{X}=0.7$ (black line) was selected for the final $P-T$ diagram.

Fig. S3: Metapelitic gneiss $P-X$ pseudosection with varying ferric iron content $(0)$ from the $\mathrm{XRF}$ measured value of $1.34(\mathrm{X}=0)$ to $0.01(\mathrm{X}=1)$. Note that higher $\mathrm{X}$ values in this diagram actually correspond to lower $\mathrm{X}_{\mathrm{Fe} 203}$ in the rock. A mid value of $\mathrm{X}=0.7$ (black line) was selected for the final $P-T$ diagram.

Table S1: All data for monazite SHRIMP U-Pb analyses

Table S2: All data for zircon SHRIMP U-Pb analyses

Table S3: All data for monazite LA-ICP-MS REE and trace element analyses

Table S4: All data for zircon LA-ICP-MS REE and trace element analyses

Table S5: All data for garnet LA-ICP-MS REE and trace element analyses

Received 5 May 2015; revision accepted 31 March 2016.

\section{FIGURE CAPTIONS}

Fig. 1: Geological map of the Southern Granulite Terrane of southern India adapted from Taylor et al. (2014) with major rock types and field locations marked. Kakkod quarry is located at $\mathrm{N} 08^{\circ} 48^{\prime} 37.6^{\prime \prime} \mathrm{E} 76^{\circ} 48^{\prime} 37.9^{\prime \prime}$, with the direction of view to the north. The Achankovil Shear Zone (ACSZ) separates the Trivandrum Block from the South Madurai Block. ACSZ, Achankovil Shear Zone; DC, Dharwar craton; SB, Salem Block; PCSS, Palghat-Cauvery Shear System; NB, Nilgiri Block; MSB, Madras Block; NMB, North Madurai Block; SMB, South Madurai Block; IB, Isotopic boundary; P, Phanerozoic cover; NCB, Nagercoil Block; TB, Trivandrum Block.

Fig. 2: Field photographs of Kakkod quarry. (a) Kakkod quarry showing three main rock types; garnet-sillimanite-cordierite gneiss (metapelitic gneiss) to the west with dark incipient charnockite patches within the grey garnet-biotite gneiss to the east. (b) Garnet-biotite gneiss with white leucosome patches. (c) Metapelitic gneiss. (d) Metapelitic gneiss (dark coloured) outcropping on top of the garnet-biotite gneiss with white leucogranite sheet. (e) Pegmatite dyke cross-cutting the garnet-biotite gneiss with yellow-brown monazite aggregates visible (f) Close-up of garnet-biotite gneiss and charnockite with a transition zone in-between.

Fig. 3: Thin section photomicrographs. (a) Garnet-biotite gneiss with type-1 garnet porphyroblast. (b) Garnet-biotite gneiss with type-2 garnet porphyroblasts. (c) Transition zone showing garnet that has reacted with $\mathrm{H}_{2} \mathrm{O} /$ melt to form retrograde biotite. (d) Partially retrogressed subhedral orthopyroxene within the charnockite with straight grain boundaries preserved. Biotite is seen replacing the orthopyroxene grain to the right on the image. (e) Orthopyroxene within the charnockite partially replaced by chlorite and other hydrosilicates. (f) Fully retrogressed orthopyroxene and anhedral 
garnet within the charnockite (g) Inclusion poor anhedral garnet (type-2) from the metapelitic gneiss. (h) Metapelitic gneiss with elongate garnet porphyroblasts (type-1) containing inclusions of sillimanite. (i) Metapelitic gneiss with sillimanite, green spinel and garnet porphyroblasts surrounded by variably pinitised cordierite.

Fig. 4: BSE and CL images for monazite and zircon from all samples. Marked ages are ${ }^{206} \mathrm{~Pb} /{ }^{238} \mathrm{U}$ SHRIMP ages for zircon and ${ }^{207} \mathrm{~Pb} /{ }^{235} \mathrm{U}$ SHRIMP ages for monazite, both with $1 \sigma$ errors. Circles represent LA-ICP-MS analytical spots that were placed over SHRIMP spots. (a) Monazite BSE images from the garnet-biotite gneiss (I11-004K). Monazite shows low BSE response cores with recrystallized zones of high BSE response. (b) Zircon CL images from the garnet-biotite gneiss with inherited oscillatory-zoned zircon cores and uniform to sector-zoned rims. (c) BSE images of monazite from the transition zone (I11-004C) showing low BSE response cores and recrystallized zones with high BSE response. (d) Monazite BSE images from the pegmatite (I11-006V) showing variable BSE response and limited zoning. A few grains have low BSE response recrystallized zones. (e) BSE images of monazite from the charnockite (I11-008C) with uniform BSE response and no internal structures. (f) Zircon CL images from the charnockite with a population of equant sector-zoned soccer ball zircon and a population of inherited oscillatory-zoned cores with uniform to sector-zoned rims. (g) Monazite BSE images from the metapelitic gneiss (TB-14-025) with most monazite showing low BSE response cores and high BSE response recrystallized zones, and a few grains with quite uniform BSE response. (h) Zircon CL images from the metapelitic gneiss with recrystallized zircon showing remnants of inherited cores and uniform CL response, and one grain with a uniform CL response rim.

Fig. 5: Calculated $P-T$ pseudosections for three bulk compositions with standardised $\mathrm{Fe}_{2} \mathrm{O}_{3}$ concentrations. Solidus indicated by black dashed line, with the peak conditions outlined by a solid black line. (a) Garnet-biotite gneiss (I11-004K) $P-T$ pseudosection. (b) Charnockite (I11-008C) $P-T$ pseudosection. (c) Metapelitic gneiss (TB-14-025) $P-T$ pseudosection.

Fig. 6: U-Pb monazite and zircon data for the samples in this study. Colours indicate textural location the analysis (see online version): red- grain core; light blue- rim (zircon) or recrystallized zones (monazite); green- 'soccerball' zircon; dark bluerecrystallized zircon. (a) All monazite analyses for the garnet-biotite gneiss. (b) All monazite analyses for the transition zone with the weighted mean age of monazite cores. (c) All monazite analyses for the charnockite. (d) All monazite analyses for the metapelitic gneiss with a few inherited monazite defining a discordia. The lower intercept of this discordant array is based on the onset of high-temperature conditions using the oldest metamorphic monazite spots and should not be interpreted as a true metamorphic age. (e) Younger population of monazite analyses from the metapelitic gneiss. (f) All monazite analyses for the pegmatite with the weighted mean age of the recrystallized zones. (g) All zircon analyses for the garnet-biotite gneiss with a few inherited zircon defining a discordia. The lower intercept of this discordant array is a mean age of the complete range of rim ages. (h) All zircon core and rim analyses for the charnockite with discordia through discordant inherited zircon. Lower intercept of this discordant array is based on the onset of high-temperature conditions using the oldest rims and should not be interpreted as a true metamorphic age. (i) All analyses of the

This article is protected by copyright. All rights reserved. 
'soccerball' zircon from the charnockite with weighted mean age of all analyses. (j) All zircon analyses for the metapelitic gneiss with weighted mean age of all analyses.

Fig. 7: Representative zircon, monazite and garnet REE analyses for samples in this study. Colours indicate textural location the analysis (see online version): red- core; light blue- rim (zircon) or recrystallized zones (monazite); green- Soccer ball zircon; dark blue- recrystallized zircon. (a) Garnet-biotite gneiss, monazite cores show little variation except for a few with low HREE compared to the recrystallized zones with lower HREE concentrations and almost an order of magnitude of variation. (b) Transition zone, monazite shows similar separation of cores and recrystallized zones to the garnet-biotite gneiss. (c) Charnockite, monazite recrystallized zones showing no variation in HREE. (d) Metapelitic gneiss, the monazite recrystallized zones mainly cluster at low HREE concentrations with a few grains with higher concentrations of HREE. The monazite cores show a high degree of scatter to the HREE and a range of Eu anomalies. (e) Pegmatite, monazite shows little differentiation between cores and recrystallized zones. (f) Garnet-biotite gneiss, zircon cores show a positive M-HREE slope with a flat M-HREE slope to the rims. (g) Charnockite, positive M-HREE slope to the cores with a less positive M-HREE slope to the rims and the soccer ball zircon. $(\mathrm{h})$ Metapelitic gneiss, recrystallized zircon shows near flat M-HREE slope with some scatter, except one grain with a negative HREE slope. The zircon rim shows a near flat M-HREE slope. (i) Garnet-biotite gneiss, type-1 garnet (solid lines) show a slightly negative M-HREE slope for both cores and rims with slightly enriched rims. Type-2 garnet (dashed lines) shows flat M-HREE slopes for both cores and rims. (j) Transition zone, garnet shows scatter and reduced concentration of HREE to the rims with an almost flat M-HREE slopes and little variation to the HREE concentration of the cores. (k) Charnockite, garnet from the charnockite shows a near flat M-HREE slope for the cores and rims with no separation. (1) Metapelitic gneiss, type-1 garnet (solid lines) show a negative M-HREE slope with slightly enriched cores and minor scatter to the rims. Type-2 garnet (dashed lines) shows almost flat M-HREE slope with some limited scatter to cores and rims.

Fig. 8: Summary diagram of $P-T$ estimates. Peak fields for each modelled $P-T$ pseudosection are overlain to show a common field of peak conditions outlined in black. Mineral isopleths show predicted modal proportions of orthopyroxene in the charnockite composition. Dashed blue lines indicate the possible conditions through which the post peak evolution might have passed based on the growth of retrograde cordierite within the metapelitic gneiss. No prograde evolution is proposed because partial melting and melt segregation mean that the present-day bulk rock compositions are not representative of prograde conditions.

Fig. 9: Summary diagram of all monazite and zircon $\mathrm{U}-\mathrm{Pb}$ geochronological data for Kakkod (excluding analyses of older inherited grains). Data are shown as box and whisker plots to illustrate the age spread of each analysis type. Box shape indicates the mineral (monazite versus zircon), while colours indicate the textural location of the analyses (see online version): red- core; light blue- rim (zircon) or recrystallized zones(monazite); green- Soccer ball zircon; dark blue- recrystallized zircon. Monazite is given as ${ }^{207} \mathrm{~Pb} /{ }^{235} \mathrm{U}$ ages. Zircon is given as ${ }^{206} \mathrm{~Pb} /{ }^{238} \mathrm{U}$ ages. The box represents the interquartile range (the middle $50 \%$ (median- horizontal bar) of the data from the $25^{\text {th }}$ to $75^{\text {th }}$ percentile), the whiskers represent the minimum and maximum ages within

This article is protected by copyright. All rights reserved. 
$1.5^{*}$ interquartile range with outliers marked with an ' $\mathrm{X}$ '. Some of overlap between the age ranges is likely a representation of the analytical uncertainty of the data. Major events interpreted from geochronology are outlined by arrowed intervals based on quartile ranges and ignoring outliers.

\section{TABLE CAPTIONS}

Table 1: Bulk rock compositions as measured by XRF and modelled composition with modified ferric values. All values are in mol.\%. $\mathrm{Fe}_{2} \mathrm{O}_{3}$ concentrations are recast into equivalent concentrations of $\mathrm{FeO}$ (added to the ferrous $\mathrm{FeO}$ concentration) and $\mathrm{O}$ (Diener \& Powell, 2010).

Table 2: Summary table of compositional ranges of LA-ICP-MS REE and other elements from monazite, zircon and garnet. Values are in ppm for singular elements or $\mathrm{ppm} /$ chondrite for REE.

Table 1. Compositions from XRF analysis converted to molar oxide \% (mol\%) for phase equilibria modelling

\begin{tabular}{lccccccccccc}
\hline & \multicolumn{10}{c}{ Measured compositions from XRF (mol \%) } \\
\hline \multicolumn{1}{c}{ Sample } & $\mathrm{SiO}_{2}$ & $\mathrm{TiO}_{2}$ & $\mathrm{Al}_{2} \mathrm{O}_{3}$ & $\mathrm{O}$ & $\mathrm{FeO}$ & $\mathrm{MgO}$ & $\mathrm{CaO}$ & $\mathrm{Na}_{2} \mathrm{O}$ & $\mathrm{K}_{2} \mathrm{O}$ & $\mathrm{LOI}$ & Total \\
\hline I11-004K Garnet-biotite gneiss & 76.32 & 0.19 & 9.39 & 0.39 & 2.56 & 1.07 & 2.56 & 4.61 & 1.23 & 1.69 & 100.01 \\
I11-008C Charnockite & 74.72 & 0.16 & 9.23 & 0.35 & 2.27 & 1.04 & 2.6 & 4.59 & 1.36 & 3.67 & 99.99 \\
TB-14-025 Metapelitic gneiss & 64.83 & 0.59 & 11.93 & 1.34 & 6.62 & 3.66 & 1.30 & 3.49 & 3.36 & 2.87 & 99.99 \\
\hline \multicolumn{1}{c}{ Sample } & \multicolumn{8}{c}{ Modelled Bulk compositions (mol\%) } \\
\hline \multicolumn{1}{c}{$\mathrm{SiO}_{2}$} & $\mathrm{TiO}_{2}$ & $\mathrm{Al}_{2} \mathrm{O}_{3}$ & $\mathrm{O}$ & $\mathrm{FeO}$ & $\mathrm{MgO}$ & $\mathrm{CaO}$ & $\mathrm{Na}_{2} \mathrm{O}$ & $\mathrm{K} 2 \mathrm{O}$ & $\mathrm{LOI}$ & Total \\
\hline I11-004K Garnet-biotite gneiss & 76.53 & 0.19 & 9.42 & 0.11 & 2.57 & 1.07 & 2.57 & 4.63 & 1.23 & 1.69 & 100.01 \\
I11-008C Charnockite & 77.00 & 0.16 & 9.52 & 0.11 & 2.34 & 1.08 & 2.68 & 4.73 & 1.40 & 1.00 & 100.02 \\
TB-14-025 Metapelitic gneiss & 65.45 & 0.60 & 12.04 & 0.40 & 6.68 & 3.69 & 1.32 & 3.53 & 3.39 & 2.9 & 100.00 \\
\hline
\end{tabular}

This article is protected by copyright. All rights reserved. 
Table 2: Summary of LA-ICP-MS REE and other elements for monazite, zircon and garnet

\begin{tabular}{|c|c|c|c|c|c|c|c|c|}
\hline Monazite & & & & & & & & \\
\hline Sample & Textural position & Y (ppm) & $\mathrm{Ca}(\mathrm{ppm})$ & Si (ppm) & Th (ppm) & $\mathrm{U}(\mathrm{ppm})$ & $\mathrm{Yb} / \mathrm{Gd}$ & $\mathrm{Eu} / \mathrm{Eu}^{*}$ \\
\hline Garnet-biotite gneiss & Core & $548-4140$ & $6630-10890$ & BDL-6710 & $91100-159800$ & $9270-15870$ & $0.001-0.008$ & $0.002-0.006$ \\
\hline I11-004K & Recrystallized zone & $473-1370$ & $10180-12240$ & $4200-17100$ & $146300-226400$ & $5730-14900$ & $0.001-0.004$ & $0.002-0.004$ \\
\hline Transition zone & Core & $2222-3643$ & $6690-9100$ & 210-1710 & $91400-133800$ & $8310-11340$ & $0.001-0.002$ & $0.001-0.004$ \\
\hline I11-004C & Recrystallized zone & $337-2695$ & $6320-10410$ & $1200-5020$ & 115000-252700 & $3990-8510$ & $0.0004-0.002$ & $0.001-0.004$ \\
\hline $\begin{array}{l}\text { Charnockite } \\
\text { I11-008C }\end{array}$ & Recrystallized zone & $1101-1640$ & $1880-13390$ & $98-2880$ & $23200-279600$ & $4390-4890$ & 0.001 & 0.002 \\
\hline Metapelitic gneiss & Core & $346-19900$ & $2860-11200$ & BDL-16500 & $32410-120100$ & $2890-10480$ & $0.0003-0.026$ & $0.002-0.075$ \\
\hline TB-14-025 & Recrystallized zone & $287-11260$ & 6010-9970 & $2100-24300$ & 64500-201900 & $1682-8560$ & $0.0002-0.007$ & $0.002-0.034$ \\
\hline Pegmatite & Core & $1214-1890$ & $7170-14400$ & BDL-17100 & 97700-183900 & $10970-40400$ & $0.004-0.006$ & $0.003-0.005$ \\
\hline I11-006V & Recrystallized zone & $1250-1363$ & $4520-9600$ & BDL-8300 & $46900-151200$ & $11810-17500$ & $0.004-0.005$ & $0.004-0.005$ \\
\hline
\end{tabular}

\section{Zircon}

Sample Garnet-biotite gneiss Textural position

$\mathrm{Y}(\mathrm{ppm})$ $\mathrm{Th} / \mathrm{U}$ $\mathrm{Yb} / \mathrm{Gd} \quad \mathrm{Eu} / \mathrm{Eu}^{*}$

I11-004K Rim 816-1450

0.03-0.075

8.21-16.41

$\mathrm{Eu} / \mathrm{Eu}$

Core

98-130

$0.04-0.13$

$0.74-1.28$

$0.03-0.38$

Charnockite

111-008C

Core

115-980

$0.11-0.31$

$11.70-14.26$

$0.13-0.28$

Rim

414-1309

$0.07-0.23 \quad 1.40-9.69$

$0.004-0.06$

'Soccerball' zircon

124-178 0.07-0.09

$2.09-2.63$

All Eu values BDL

\begin{tabular}{lcccc} 
Metapelitic gneiss & Rim & 138 & 0.125 & 0.39 \\
TB-14-025 & Recrystallized & $37-326$ & $0.012-0.24$ & $0.06-1.28$ \\
& & & & \\
\hline Garnet & & & & \\
Sample & Textural position & Y (ppm) & Yb/Gd & Eu/Eu* \\
\hline Garnet-biotite gneiss & Type 1 - Core & $121-141$ & $0.53-0.91$ & $0.001-0.002$ \\
I11-004K & Type 1 - Rim & $117-141$ & $0.58-0.84$ & 0.005 \\
& Type 2 - Core & $79-117$ & $0.06-0.12$ & $0.001-0.010$ \\
& Type 2 - Rim & $103-126$ & $0.17-0.23$ & $0.001-0.004$ \\
Transition zone & Core & $94-150$ & $0.31-0.44$ & $0.002-0.005$ \\
I11-004C & Rim & $4-13$ & $0.012-0.038$ & 0.005 \\
Charnockite & Core & $106-123$ & $0.43-1.19$ & $0.002-0.006$ \\
I11-008C & Rim & $94-122$ & $0.44-1.35$ & $0.001-0.005$ \\
& & & & \\
Metapelitic gneiss & Type 1 - Core & $53-84$ & $0.042-0.13$ & $0.005-0.008$ \\
TB-14-025 & Type 1 - Rim & $56-75$ & $0.043-0.091$ & $0.005-0.011$ \\
& Type 2 - Core & $72-100$ & $0.175-0.363$ & $0.005-0.007$ \\
& Type 2 - Rim & $78-121$ & $0.173-0.457$ & $0.004-0.006$ \\
\hline BDL-Ben & & & &
\end{tabular}

BDL- Below detection limit

This article is protected by copyright. All rights reserved. 


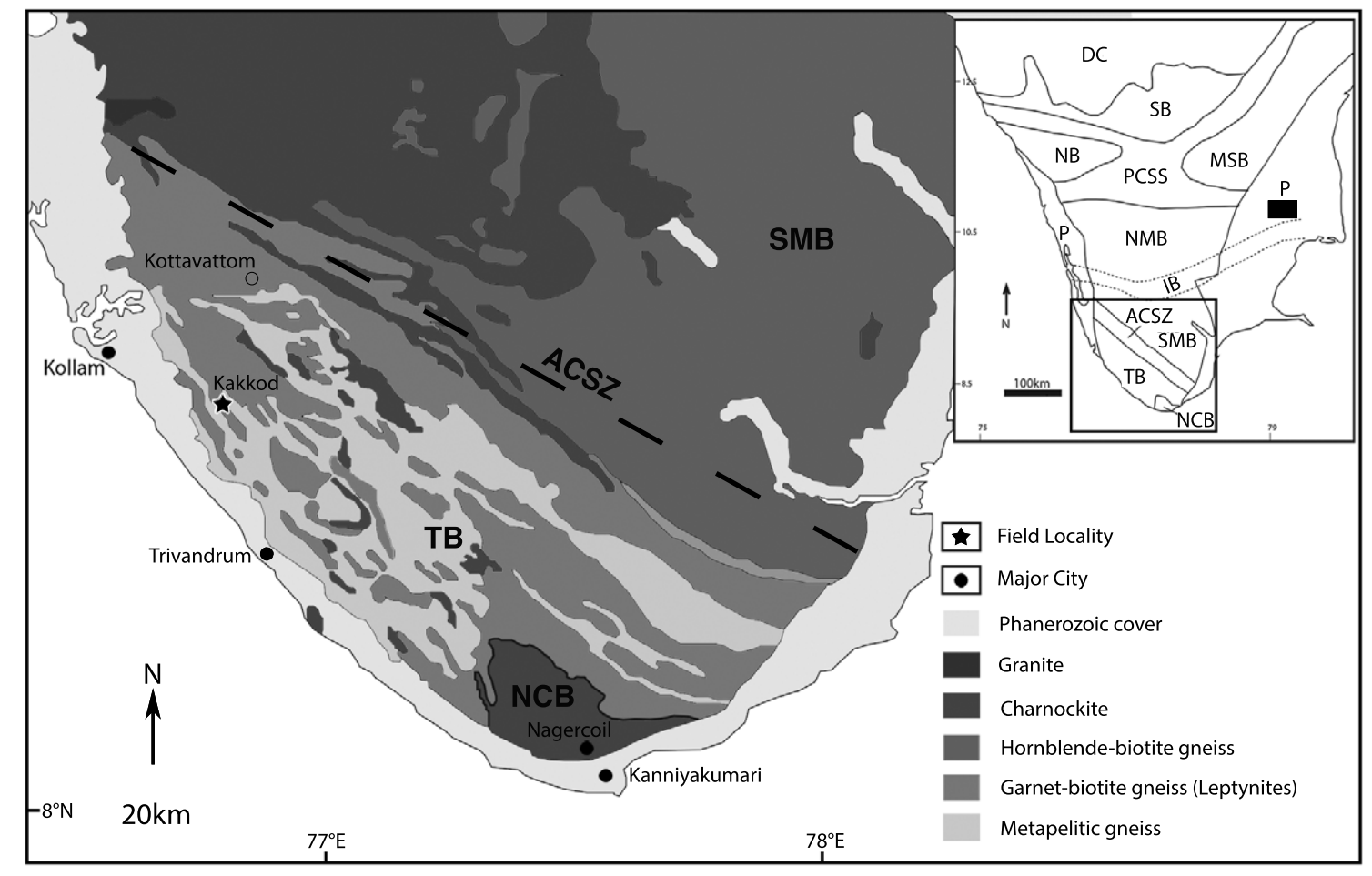

This article is protected by copyright. All rights reserved. 
(a) W

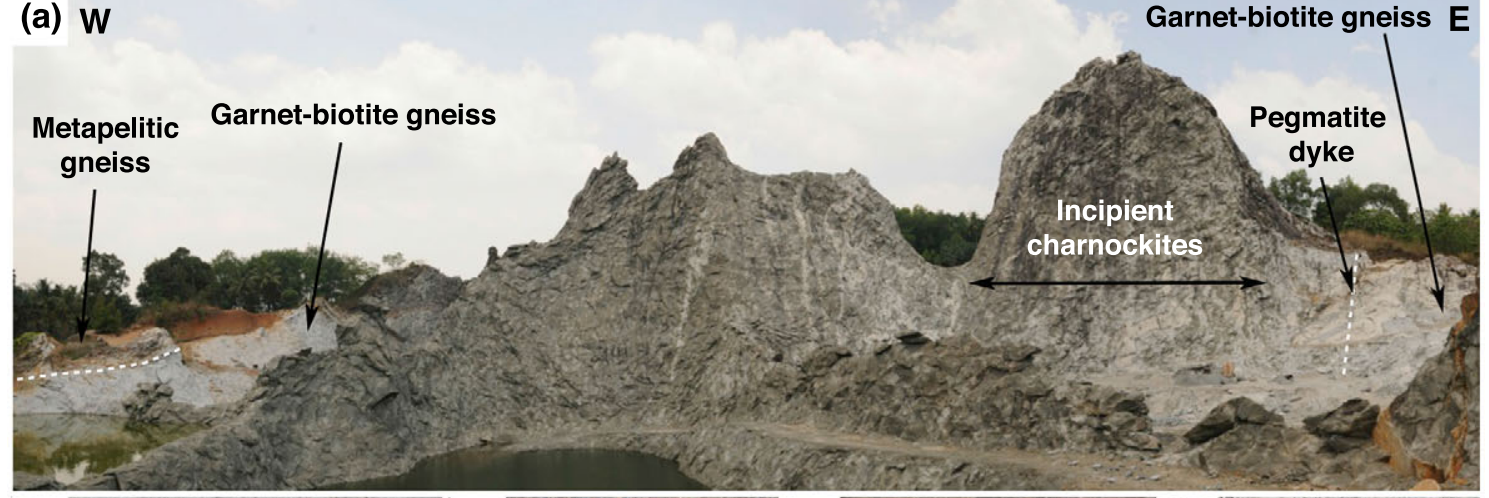

(b)

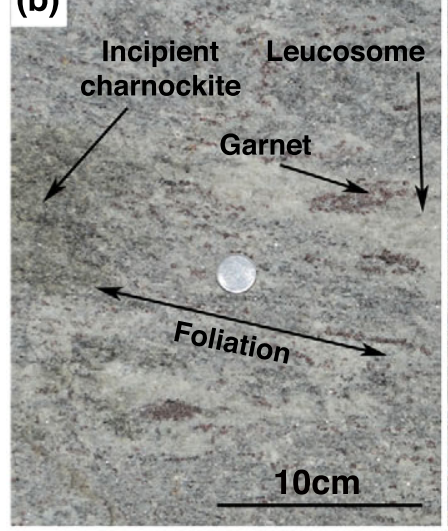

(c)

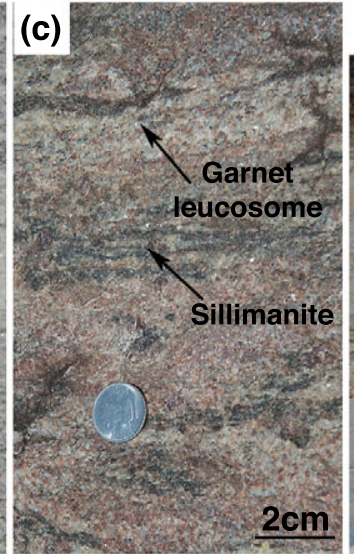

(d)
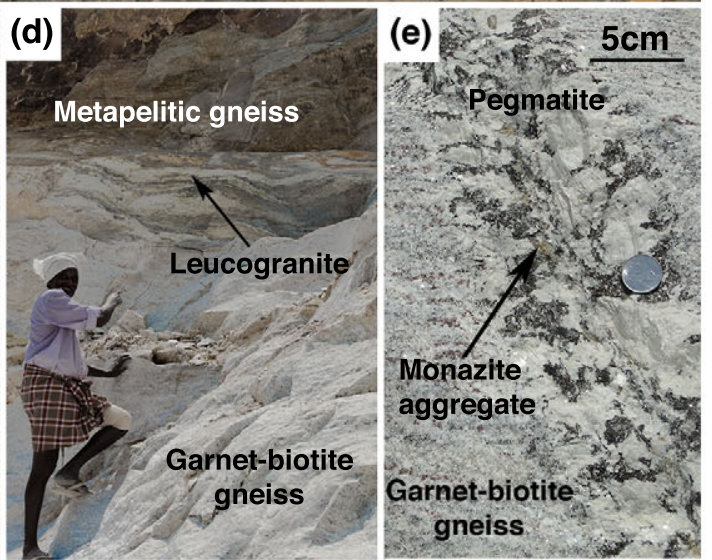

(f) $5 \mathrm{~cm}$

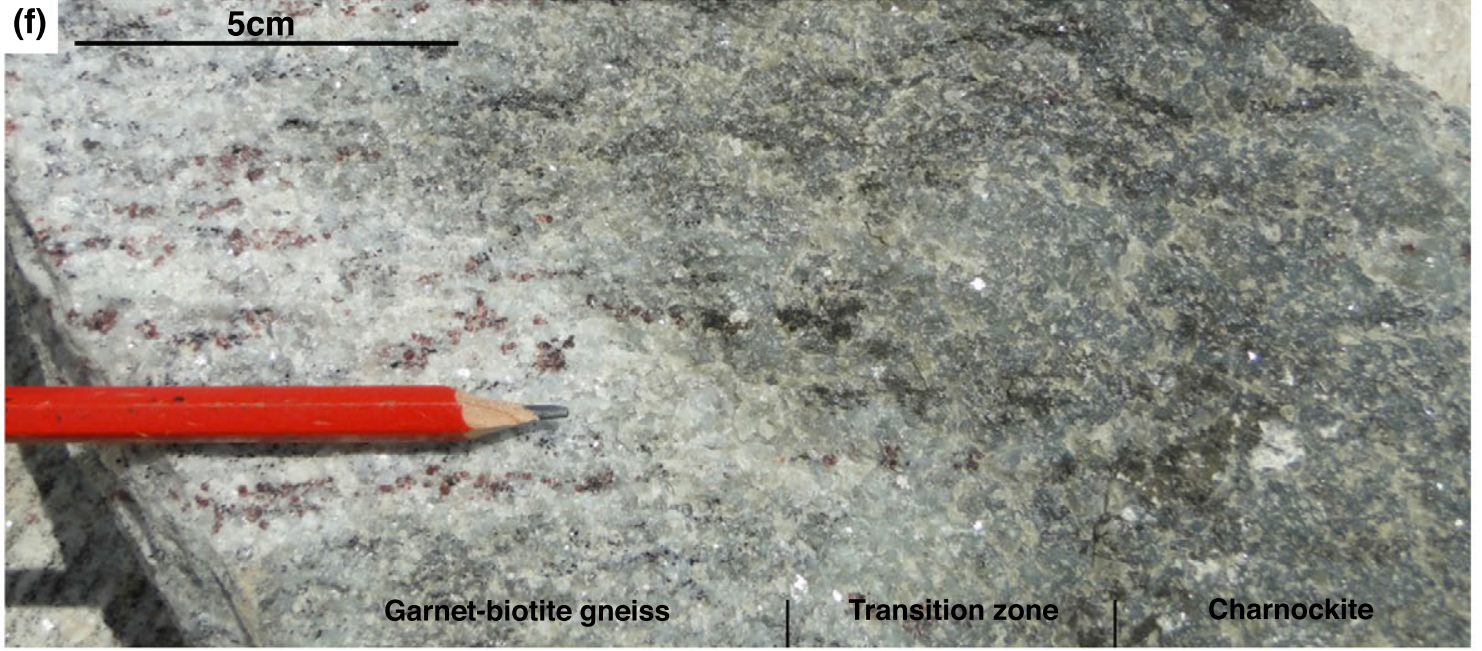

This article is protected by copyright. All rights reserved. 

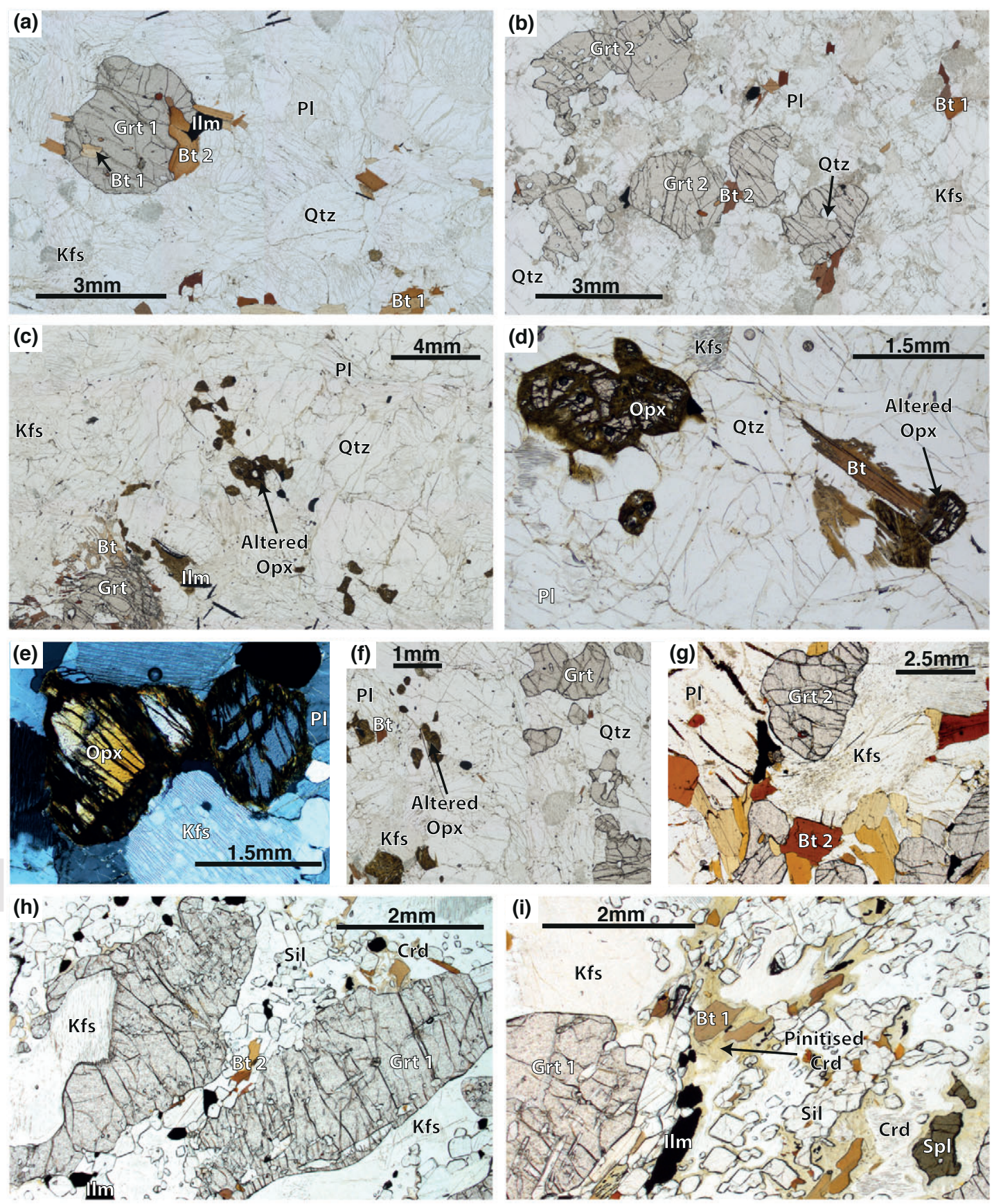

This article is protected by copyright. All rights reserved. 


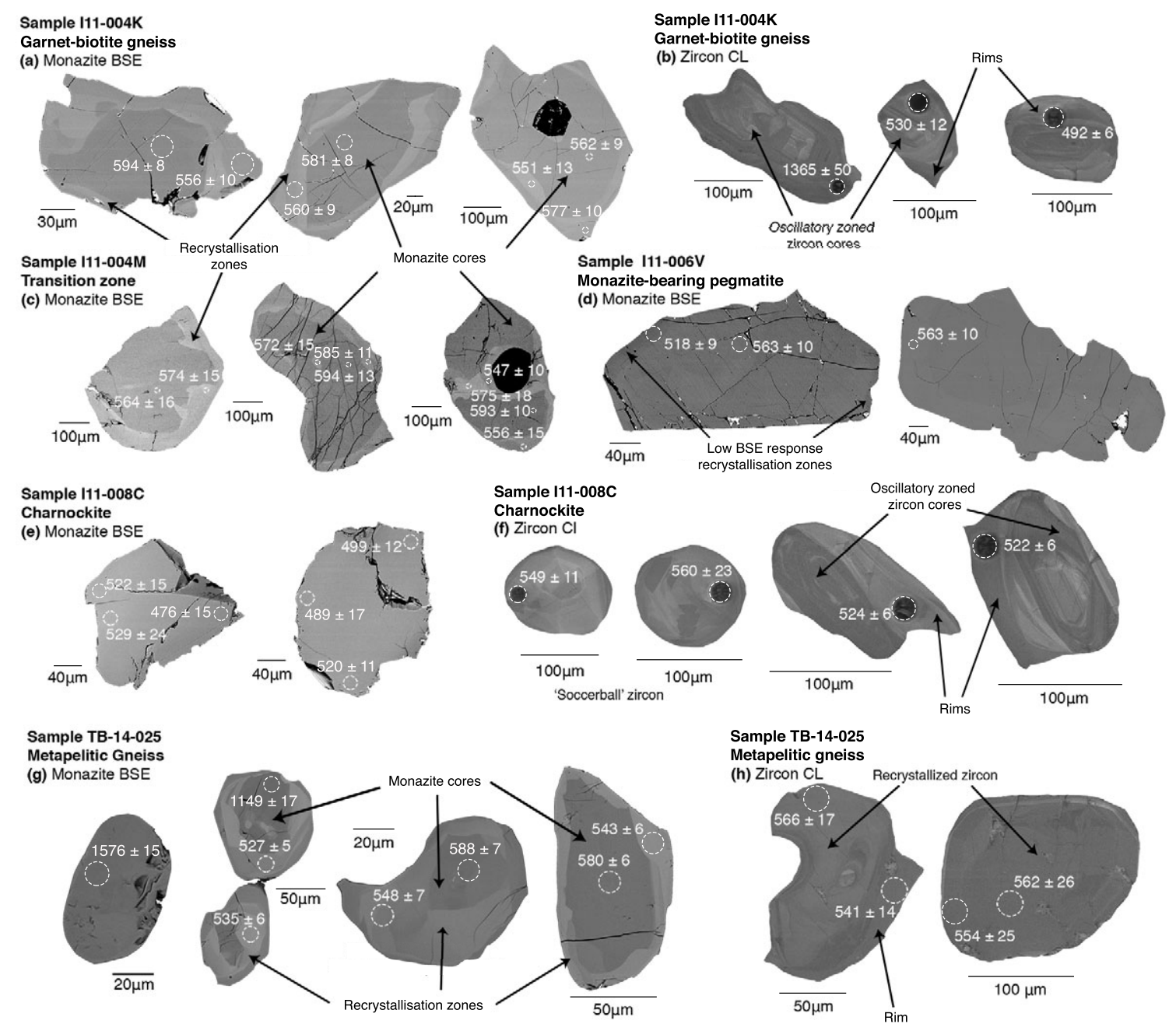

This article is protected by copyright. All rights reserved. 

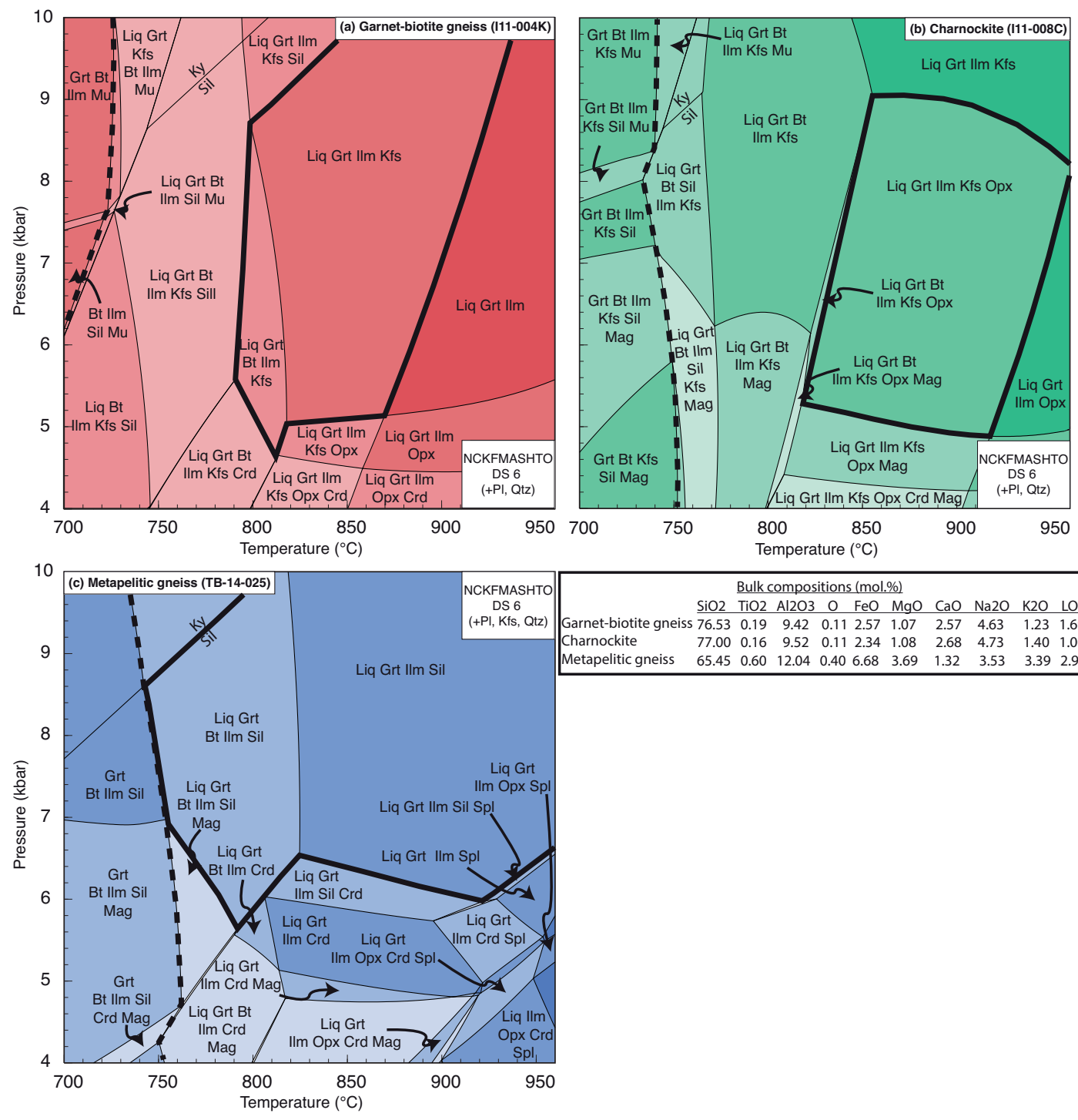

This article is protected by copyright. All rights reserved. 

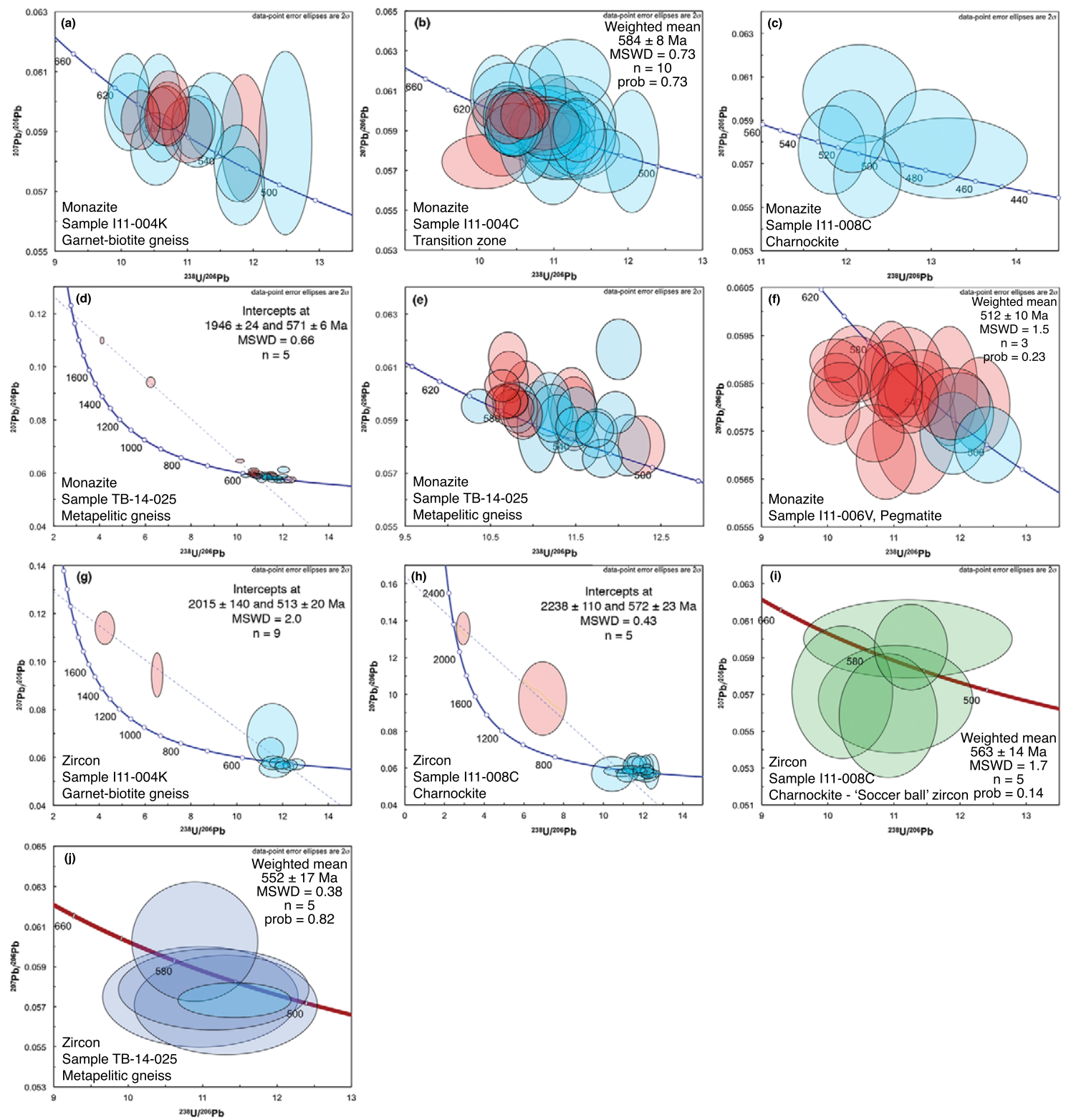

This article is protected by copyright. All rights reserved. 

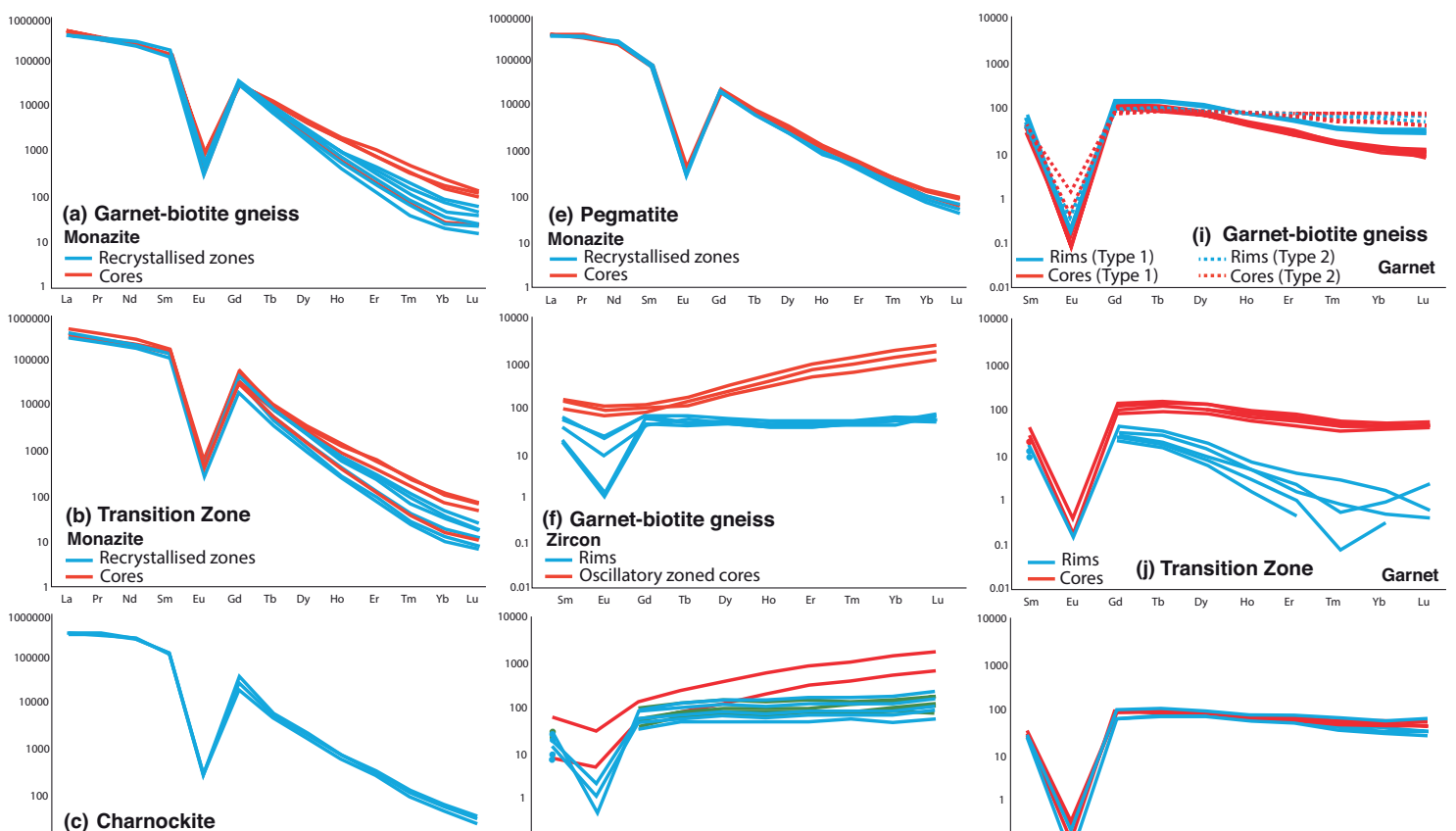

(c) Charnockite

Monazite

— Recrystallised zones
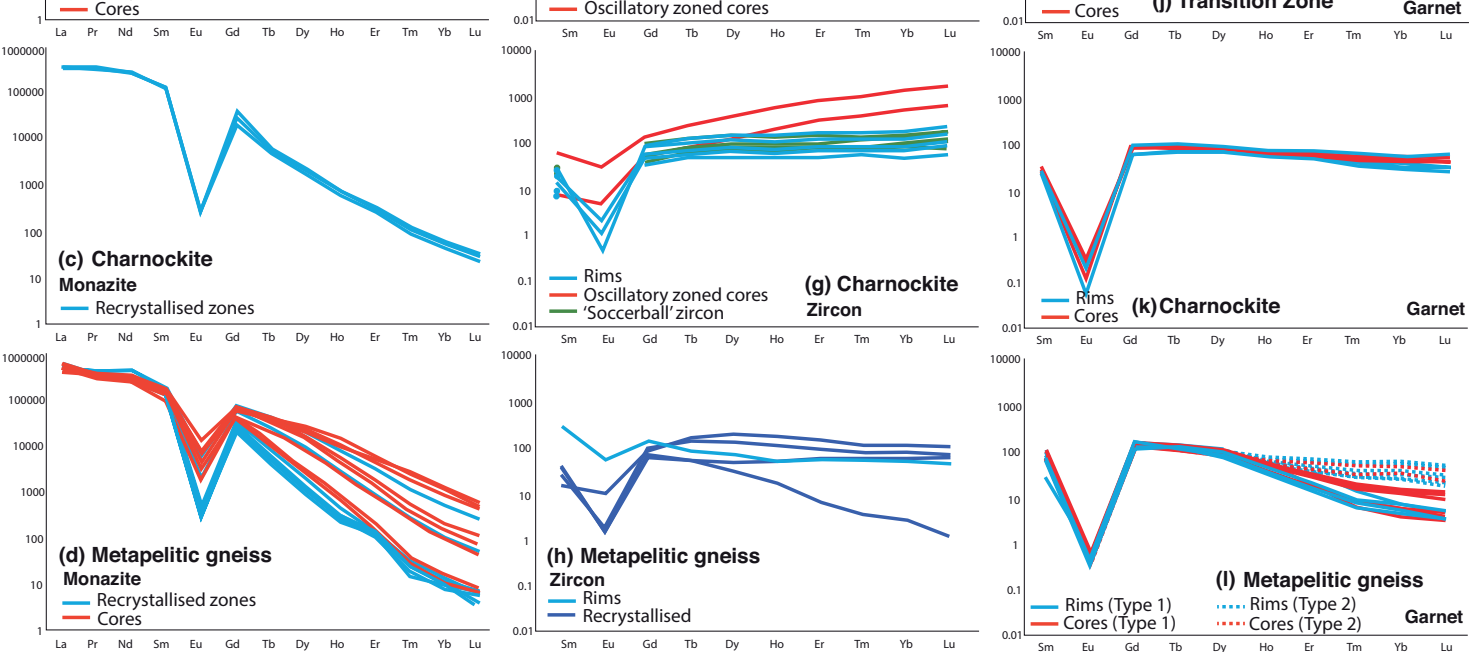

This article is protected by copyright. All rights reserved. 


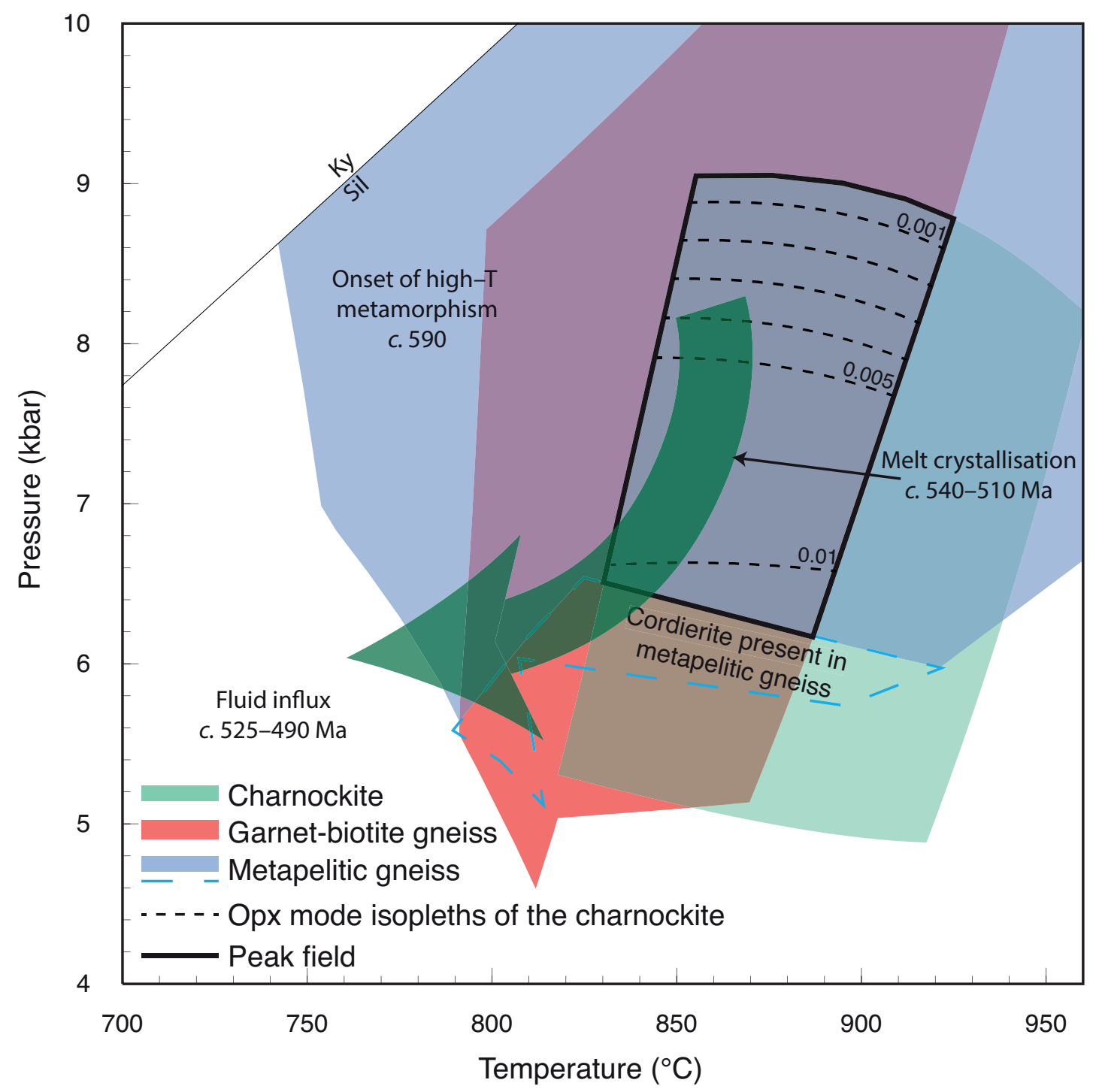

This article is protected by copyright. All rights reserved. 


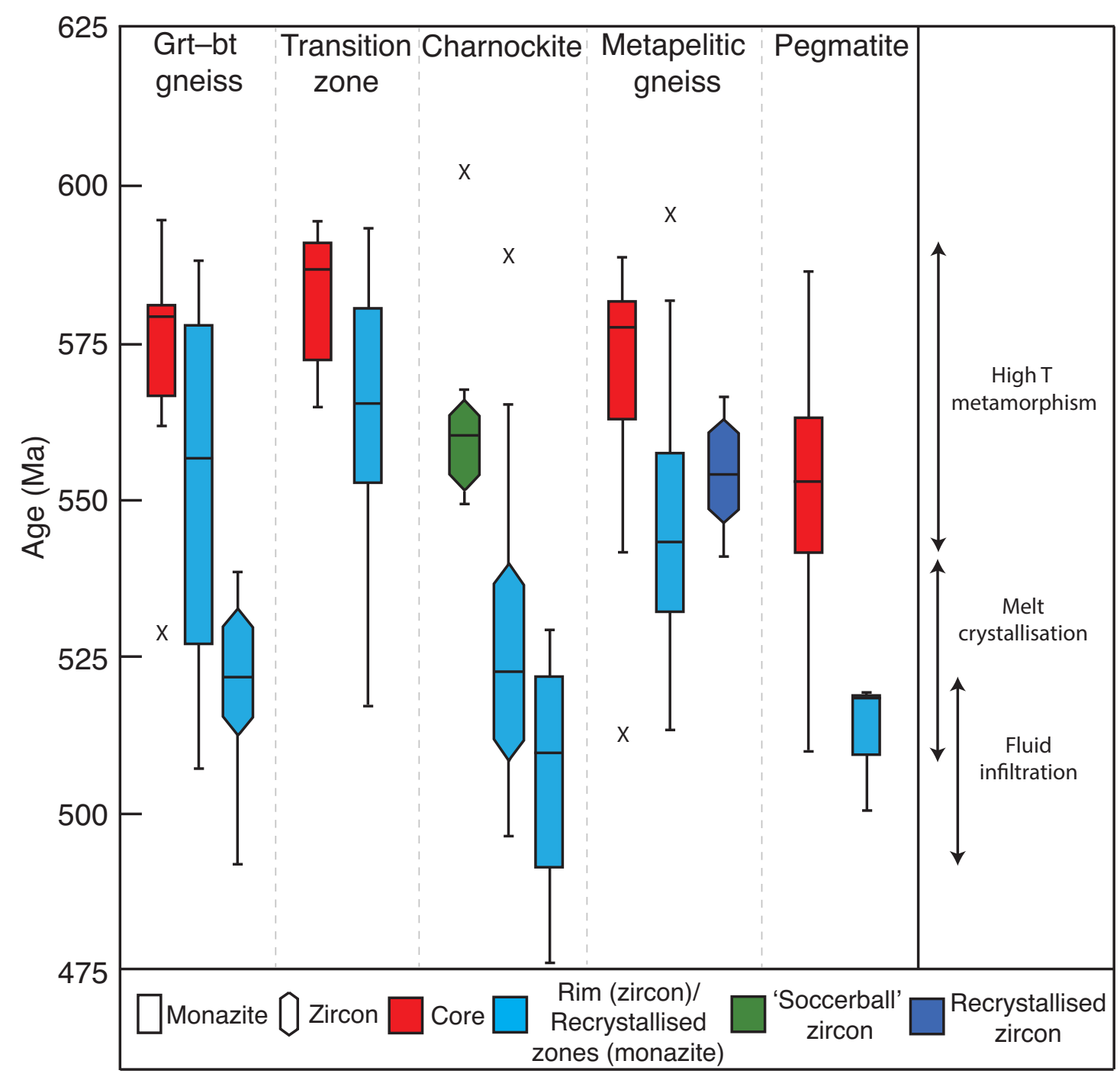

This article is protected by copyright. All rights reserved. 